1978

\title{
Young Adults As a Cognizable Group in Jury Selection
}

Donald H. Zeigler

New York Law School, donald.ziegler@nyls.edu

Follow this and additional works at: http://digitalcommons.nyls.edu/fac_articles_chapters

Part of the Litigation Commons, and the Supreme Court of the United States Commons

\section{Recommended Citation}

76 Mich. L. Rev. 1045 (1977-1978)

This Article is brought to you for free and open access by the Faculty Scholarship at DigitalCommons@NYLS. It has been accepted for inclusion in Articles \& Chapters by an authorized administrator of DigitalCommons@NYLS. 


\title{
YOUNG ADULTS AS A COGNIZABLE GROUP IN JURY SELECTION
}

\author{
Donald H. Zeigler*†
}

\section{INTRODUCTION}

It is a fundamental principle of American jurisprudence that jurors are to be chosen from a representative cross section of the community. This maxim has been articulated in cases construing the sixth amendment right to a jury trial, ${ }^{1}$ the equal protection guarantee, ${ }^{2}$ and the Supreme Court's supervisory power over federal courts. $^{3}$ Nevertheless, young adults are substantially underrepresented on the nation's jury rolls. ${ }^{4}$ In some jurisdictions, the

* Associate Professor of Law, Pace University. A.B. 1966, Amherst College; J.D. 1969, Columbia University.-Ed.

$\dagger$ The author gratefully acknowledges the assistance of Richard Faust, Josephine Carlson, Jay Schulman, Eric Swanson, Gerard Gilbride, Elissa Krause, Lee O'Brien, and the National Jury Project in designing the public opinion survey described herein, in supervising its administration, in analyzing the data, and in presenting the results. Special thanks are extended to the many volunteers who conducted the survey. The author also gratefully acknowledges the assistance of Anne Foner. This research was undertaken for a lawsuit challenging the exclusion of young adults from the grand jury rolls in Queens County, New York. See notes 5, 6, Part III infra. The litigation was conducted by the author while he was Attorney-inCharge, Special Litigation Unit, The Legal Aid Society of the City of New York. The litigation became moot due to substantial alteration in Queens County grand jury selection procedures mandated by a change in state law. See N.Y. JuD. LAw $\S \S 500-23$ (McKinney Supp. 1978).

1. See Taylor v. Louisiana, 419 U.S. 522, 526-31 (1975).

2. See Smith v. Texas, 311 U.S. 128, 130 (1940).

3. See Thiel v. Southern Pac. Co., 328 U.S. 217, 220 (1946). The principle is now also recognized by the Jury Selection and Service Act of 1968, $\$ \$ 101-04,28$ U.S.C. $\$ \$ 1861-74$ (1976).

4. The pattern may be observed from Maine to California. See, e.g., United States v. Ross, 468 F.2d 1213, 1216-17 (9th Cir. 1972), cert. denied, 410 U.S. 989 (1973) (persons aged 21-24 substantially excluded from federal petit jury panels in the Northern District of California); Chase v. United States, 468 F.2d 141, 143-44 (7th Cir. 1972) (persons under age 25 inadequately represented on federal petit and grand jury rolls in the Eastern Division of the Northern District of Illinois); United States v. Butera, 420 F.2d 564, 569 n.13 (1st Cir. 1970) (young adults aged 21-34 underrepresented on federal grand jury rolls for the District of Maine); Quadra v. Superior Court, 378 F. Supp. 605, 622-23 (N.D. Cal. 1974) (young adults aged 21-40 substantially underrepresented on state grand jury rolls for County of San Francisco); United States v. Briggs, 366 F. Supp. 1356, 1362 (N.D. Fla. 1973) (young people aged 21-29 underrepresented on federal petit jury rolls for the Northern District of Florida); United States v. Gargan, 314 F. Supp. 414, 415-16 (W.D. Wis. 1970), affd. sub nom. United States v. Gast, 457 F.2d 141 (7th Cir.), cert. denied, 406 U.S. 969 (1972) (persons aged 18-21 totally excluded and those aged 21-26 substantially underrepresented on federal grand jury rolls for the Western District of Wisconsin); Julian v. State, 134 Ga. App. 592, 594, 215 S.E.2d 496, 497 (1975) (93\% of grand jury pool consisted of white males whose average age was 69 years). Data docu- 
young are victims of overt discrimination. 5 In others, selection procedures neutral on their face systematically exclude young adults. Maintaining juror pools permanently, ${ }^{6}$ or even for two to four years, ${ }^{7}$ results in underrepresentation of the young, as does using source lists on which the young are not adequately represented. ${ }^{8}$

menting the underrepresentation of young adults on petit and grand jury rolls in 12 federal judicial districts and in 29 cities and counties in 14 different states are presented in J. VAN Dyke, Jury Selection Procedures 331 app. H (1977).

5. The young sometimes are excluded by law. Five states-Mississippi, Missouri, Nebraska, Rhode Island and Utah-still require jurors to be 21 years old. MISS. CODE ANN. § 13-5-1 (1972); Mo. Rev. STAT. § 494.010 (1969); NeB. Rev. STAT. § 25-1601 (1975); R.I. GEN. LAws § 9-9-1 (Supp. 1976); UTAH CODE ANN. § 78-46-8 (1977). For a discussion of such exclusion, see note 171 infra.

Occasionally, juror selection officials openly admit that they discriminate. For example, until recently New York County officials did not solicit anyone under 35 to serve on a grand jury. United States ex rel. Chestnut v. Criminal Court, 442 F.2d 611, 613 (2d Cir.), cert. denied, 404 U.S. 856 (1971). Similarly, until new procedures went into effect January 1, 1978, officials in Queens County, New York, asked only older people if they wished to volunteer for grand jury service. Stipulated Factual Statement ๆ 42, Johnson v. Durante, No. 73C 1159-EN (E.D.N.Y., filed Aug. 3, 1973). The Deputy Commissioner of Jurors in Erie County, New York, automatically exempted those who indicated on their questionnaires that they were students, People v. Attica Bros., 79 Misc. 2d 492, 495, 359 N.Y.S.2d 699, 704 (Sup. Ct. 1974), while the Assistant Commissioner of Jurors in Albany County, New York, did not even send questionnaires to persons listed as students in town directories, People v. Marr, 67 Misc. 2d 113, 115, 324 N.Y.S.2d 608, 611 (Just. Ct. 1971). See also Anderson v. Casscles, 531 F.2d 682 (2d Cir. 1976).

6. The maintenance of permanent juror pools inevitably causes severe underrepresentation of young people. In Queens County, New York, for example, juror officials maintained a permanent pool of approximately 6,000 grand jurors. Only approximately 350 new grand jurors were placed in the pool each year. Stipulated Factual Statement 1014 48-49, Johnson v. Durante, No. 73C 1159-EN (E.D.N.Y., filed Aug. 3, 1973). Even if young adults had been proportionately represented among the new jurors, the passage of time would have ensured that the jury pool was composed primarily of older people. The maintenance of the permanent pool, together with the discriminatory practices described in note 5 supra, produced a striking underrepresentation of the young on the Queens grand jury rolls. Although persons aged 1830 made up $27.0 \%$ of the eligible population, only $5.3 \%$ of persons on the 1975 rolls were in that age group. Stipulated Factual Statement $9 \rrbracket 60,65$ a, Johnson v. Durante, No. 73C 1159EN (E.D.N.Y., filed Aug. 3, 1973).

People v. Bartlett, 89 Misc. 2d 874, 881-83, 393 N.Y.S.2d 866, $871-72$ (Sup. Ct. 1977), condemned petit jury selection procedures on Staten Island, New York, which operated to exclude young people in much the same way as the procedures in Queens. The court stated:

Richmond County has not fully reconstituted its jury pool since 1940 . Once the pool stabilized at 18,000 , no new persons were added except to replace those who died or otherwise no longer qualified. These replacements, even if statistically reflecting the age of the community at the time added, never amounted to more than 2,000 persons in any year and could not balance off the aging panel.

89 Misc. $2 \mathrm{~d}$ at 882,393 N.Y.S.2d at 871.

7. The 1972 amendment to the Jury Selection and Service Act of 1968 allows each federal judicial district to maintain a pool of jurors for up to four years. Act of Apr. 6, 1972, Pub. L. No. 92-269, § 2, 86 Stat. 117 (codified at 28 U.S.C. $\$ 1863(b)(4)$ (1976)). Although the young as a whole are not as severely underrepresented in such pools as they are in permanent pools, persons aged 18-21 are nevertheless totally excluded from service by the fourth year of their use. See text at notes $140-41$ infra.

8. Both federal and state courts rely predominantly upon voter rolls as a source of jurors. See J. VAN DYKE, 257 app. A, 261 app. B. Young adults, however, generally are underrepresented on the nation's voter rolls. One study demonstrated that only $58.1 \%$ of persons aged $18-20,59.5 \%$ of persons aged $21-24$ and $66.1 \%$ of persons aged $25-29$ register to vote, 
Moreover, the young may be less willing to serve than their elders ${ }^{9}$ - service can interfere with schooling or child care and can be economically burdensome. ${ }^{10}$ Finally, the great mobility ${ }^{11}$ of young people makes it difficult to solicit them for jury service.

Courts generally have failed to correct underrepresentation of the young, and commentators have had little to say about it. Judges have lamented the underrepresentation caused by the unwillingness of the young to serve but have declined to remedy it, ${ }^{12}$ since the law requires only that the selection process begin with a representative cross section and that identifiable groups not be intentionally or systematically excluded. ${ }^{13}$ Where complaints have demonstrated that underrepresentation was either intentional or systematic, courts usually have denied relief on the ground that young people are not a sufficiently distinct and cohesive group to be "cognizable" for jury selection purposes. ${ }^{14}$ Thus, underrepresentation of the young has been largely insulated from challenge.

while as many as $80.2 \%$ of those aged 55-64 register. U.S. BUREAU OF THE CENSUS, CURRENT Population Reports, Series P-20, No. 253, Voting and Registration in the Election of November 1972 (1973). See also Alker, Hosticka \& Mitchell, Jury Selection as a Biased Social Process, 11 LAw \& SocY. REv. 9 (1976). Nonetheless, virtually every court which has considered the exclusive use of voter rolls has approved the practice. See, e.g., Murrah v. Arkansas, 532 F.2d 105, 106 (8th Cir. 1976); United States v. James, 528 F.2d 999, 1022 (5th Cir. 1976), cert. denied, 429 U.S. 959 (1977); United States v. Lewis, 472 F.2d 252, 256 (3d Cir. 1973); United States v. Guzman, 468 F.2d 1245, 1248 (2d Cir. 1972), cert. denied, 410 U.S. 937 (1973); United States v. Gast, 457 F.2d 141, 142 (7th Cir.), cert. denied, 406 U.S. 969 (1972); United States v. Parker, 428 F.2d 488, 489 (9th Cir.), cert. denied, 400 U.S. 910 (1970); People v. Sirhan, 7 Cal. 3d 710, 749-51, 497 P.2d 1121, 1148-49, 102 Cal. Rptr. 385, 412-13 (1972), cert. denied, 410 U.S. 947 (1973); People v. Breckenridge, 52 Cal. App. 3d 913, 921, 125 Cal. Rptr. 425,429 (1975). A compendium of such cases may be found in J. VAN DYKE, supra note 4, at 77 n.18. At least one court has ordered supplementation of voter lists, Ford v. Hollowell, $385 \mathrm{~F}$. Supp. 1392, 1399-400 (N.D. Miss, 1974). Another has endorsed the proposition that "[t]he voting list is not the end sought but only the means used to ensure that all cognizable groups within the populace are represented on juries. The voting list cannot be adequate if some groups are significantly underrepresented, regardless of the cause." United States v. Armsbury, 408 F. Supp. 1130, 1140 (D. Ore. 1976).

9. See, e.g., United States v. Ross, 468 F.2d 1213, 1217 (9th Cir. 1972); United States v. DiTommaso, 405 F.2d 385, 389 (4th Cir. 1968), cert. denied, 394 U.S. 934 (1969); United States v. Leonetti, 291 F. Supp. 461,477 (S.D.N.Y. 1968).

10. See generally J. VAN DYKE, supra note 4, at 124, 391-94 app. K.

11. In a typical year, $42.6 \%$ of persons between the ages of 20 and 24 change their residence, while only $9.1 \%$ of those aged 45 to 64 move. U.S. BUREAU OF THE CENSUS, STATISTICAL ABSTRACT OF THE UNITED STATES: 1973, at 37 (94th ed. 1974).

12. See, e.g., Cobbs v. Robinson, 528 F.2d 1331, 1335-36 (2d Cir. 1975), cert. denied, 424 U.S. 947 (1976); United States v. DiTommaso, 405 F. 2d 385, 391 (4th Cir. 1968), cert. denied, 394 U.S. 934 (1969).

13. Taylor v. Louisiana, 419 U.S. 522, 538 (1975); Swain v. Alabama, 380 U.S. 202, 208 (1965); Thiel v. Southern Pac. Co., 328 U.S. 217, 220 (1946). On a broader view, however, systematic exclusion might subsume exclusion due to unwillingness to serve as well as exclusion directly due to state practices.

14. See Part II infra. On cognizability for jury selection purposes generally, see J. VAN DYKE, supra note 4, at 47-49, 62-72; Gewin, An Analysis of Jury Selection Decisions, printed in Foster v. Sparks, 506 F.2d 805, 811 app., at 819-28 (5th Cir. 1975); Kairys, Juror Selection: The Law, a Mathematical Method of Analysis, and a Case Study, 10 AM. CRIM. L. REv. 771, 780-82 
A leading case has held that a group is cognizable if it has a definite composition, is cohesive, and if its exclusion might result in bias by juries hearing cases in which group members are involved. ${ }^{15}$ This Article contends that young adults meet these requirements and therefore are entitled to judicial review of the merits of their underrepresentation claims. ${ }^{16}$ The young are a distinct and identifiable group. They share attitudes, ideas, and experiences which are not adequately expressed on jury panels on which the young are underrepresented. Such underrepresentation thus produces bias against young criminal defendants and distorts deliberation.

In support of its thesis, this Article presents what the literature has failed to provide: a comprehensive analysis of the concept of cognizability and empirical data. Part I traces the history of cognizability; identifies the sources of the cross-sectional right; and defines the criteria of cognizability, drawing special attention to the interests which a designation of cognizability protects. Part I also discusses the different approaches courts have taken to cognizability and suggests several factors which may explain the many treatments of the concept.

Part II reviews the case law concerning the cognizability of young adults in particular. That Part also examines the traditional criteria of cognizability.

Part III demonstrates that young adults satisfy the criteria of cognizability. The practical problem of defining age groups is addressed and the importance of age in determining general attitudes and outlook is explained. Since part of the rationale for broad representation on jury panels is that the quality of deliberation and the results it produces are at stake, this Article offers evidence directly related to that question-the results of a public-opinion survey of attitudes on matters of signal importance to jury service. ${ }^{17}$ Analysis of the data reveals significant and consistent differences in attitudes among persons in different age groups on criminal justice issues in general and on petit and grand jury service in particular. The great-

(1972); Comment, Underrepresentation of Economic Groups on Federal Juries, 57 B.U.L. Rev. 198 (1977); Note, Federal Courts-Juror Selection-Underrepresentation of Young Adults on Juror Source Lists, 19 WAYNE L. REv. 1287 (1973); Note, Limiting the Peremptory Challenge: Representation of Groups on Petit Juries, 86 Y ALE L.J. 1715, 1735-38 (1977).

15. United States v. Guzman, 337 F. Supp. 140, 143-44 (S.D.N.Y.), affd., 468 F.2d 1245 (2d Cir. 1972), cert. denied, 410 U.S. 937 (1973).

16. This Article does not discuss the correctness of decisions which have reached the merits and rejected jury discrimination claims by the young. Its concern is cognizability.

17. See Part IV infra. 
est disparities in attitudes are between the youngest (18-30) and the oldest (61-75) age groups, and both groups are remarkably cohesive in their attitudes toward the issues probed. (Not surprisingly, older people are much more likely to be biased against the young than are younger people.) Finally, the data show that the correlations between attitudes and age are significantly stronger than the correlations between attitudes and race, sex, occupation, or income. Since racial groups, women, and, on occasion, occupational and income groups have been held cognizable, the data strongly suggest that young adults are cognizable a fortiori.

\section{The Concept of Cognizability}

\section{A. Historical Development}

The right to a jury drawn from a fair cross section of the community is violated only by discrimination against "cognizable" groups. The right itself has several statutory and constitutional sources. Definitions of cognizability have therefore occurred in several different contexts. Although cognizability was originally an equal protection concept, ${ }^{18}$ it has also been employed by the Supreme Court in the exercise of its federal supervisory powers to define the scope of the right to a jury trial in federal courts in both civil ${ }^{19}$ and criminal $^{20}$ cases. The Jury Selection and Service Act of $1968^{21}$ specifically declares the cross-sectional ideal to be federal policy. ${ }^{22}$ More recently, the Supreme Court's holding that state courts are bound by the sixth amendment's fair-cross-section requirement ${ }^{23}$ created yet another forum for the application of the concept.

The Supreme Court first considered the issue of cognizability in 1879 in Strauder $v$. West Virginia. ${ }^{24}$ A black defendant sought to remove his criminal case to federal court on the ground that blacks were explicitly barred from jury service by state law. ${ }^{25}$ In sustaining the defendant's equal protection objection, the Court identified a number of constitutional values impaired by the exclusion.

18. See Hernandez v. Texas, 347 U.S. 475, 476-82 (1954); Strauder v. West Virginia, 100 U.S. 303, 307-10 (1879).

19. See Thiel v. Southern Pac. Co., 328 U.S. 217 (1946).

20. See Ballard v. United States, 329 U.S. 187 (1946).

21. Jury Selection and Service Act of 1968, $\S \S 101-04,28$ U.S.C. $\S \S 1861-74$ (1976).

22. 28 U.S.C. $\$ 1861$ (1976).

23. Taylor v. Louisiana, 419 U.S. 522 (1975).

24. 100 U.S. 303 (1879).

25. A removal statute permitted defendants who were denied their civil rights in state courts to remove their cases to federal court. 100 U.S. at 311. 
First, barring blacks from juries endangered the defendant's right to a fair trial. The Court reasoned that if a black defendant were tried by a jury from which all blacks were excluded, decisions might be made not by an impartial assessment of the facts but on the basis of the defendant's race: "It is well known that prejudices often exist against particular classes in the community, which sway the judgment of jurors, and which, therefore, operate in some cases to deny to persons of those classes the full enjoyment of that protection which others enjoy."26 Second, excluding blacks from juries injured members of the excluded class. To deny "the privilege of participating equally ... in the administration of justice"27 stigmatized the entire excluded group, even those who might not wish to participate. It implied that they are unfit for service, and was "practically a brand upon them . . . an assertion of their inferiority . . .."28

Strauder assumed that blacks were cognizable for jury selection purposes. It took judicial notice of the effects of past discrimination and of the need to protect blacks against continuing bias. But the Court in dictum limited cognizability to racial groups:

We do not say that within the limits from which it is not excluded by the amendment a State may not prescribe the qualifications of its jurors, and in so doing make discriminations. It may confine the selection to males, to freeholders, to citizens, to persons within certain ages, or to persons having educational qualifications. We do not believe the Fourteenth Amendment was ever intended to prohibit this. ${ }^{29}$

The Court did not discuss the issue of cognizability again until the $1940 \mathrm{ss}^{30}$ Then, in a series of four decisions, it enumerated new cognizable groups and identified additional interests protected by

26. 100 U.S. at 309.

27. 100 U.S. at 308.

28. 100 U.S. at 308.

29. 100 U.S. at 310. The Court intimated that racial or ethnic groups other than blacks also are cognizable: "Nor if a law should be passed excluding all naturalized Celtic Irishmen [from jury service], would there be any doubt of its inconsistency with the spirit of the [fourteenth] amendment." 100 U.S. at 308.

30. During the intervening years, the Supreme Court generally was unreceptive to jury challenges. The Court did condemn state statutes authorizing racial discrimination in juror selection. See, e.g., Bush v. Kentucky, 107 U.S. 110 (1882); Neal v. Delaware, 103 U.S. 370 (1880). In addition, the Court occasionally reversed a conviction and remanded for further proceedings when the state court refused even to hear evidence of alleged racial discrimination. See, e.g., Rogers v. Alabama, 192 U.S. 226 (1903); Carter v. Texas, 177 U.S. 442 (1900). More often, however, the Court relied upon procedural barriers to deny relief. Virginia v. Rives, 100 U.S. 313 (1880), and Gibson v. Mississippi, 162 U.S. 565 (1896), held that the removal statute used in Strauder was not available where jury officials had excluded blacks from juries because of their race without authority derived from the state constitution or laws. The proper remedy for challenging such de facto discrimination, the Court stated, was by way of a motion to quash the indictment, and if necessary, through normal state appellate procedures. Relief therefore was denied in both cases. Similarly, In re Wood, 140 U.S. 278 (1891), held that federal habeas corpus was not available to a state prisoner who had not properly 
fully representative juries. In Smith $v . T e x a s,{ }^{31}$ an equal protection challenge to grand jury selection procedures, the Court reiterated the value of a cross-sectional jury, which it had recognized at least implicitly in Strauder. ${ }^{32}$ "It is part of the established tradition in the use of juries as instruments of public justice that the jury be a body truly representative of the community," 33 the Court stated. "For racial discrimination to result in the exclusion from jury service of otherwise qualified groups not only violates our Constitution and the laws enacted under it but is at war with our basic concepts of a democratic society and a representative government." 34

Glasser v. United States ${ }^{35}$ applied these principles in interpreting the right to jury trial in federal courts. ${ }^{36}$ Under the federal jury selection statute then in force, jurors in federal courts were to have the qualifications of jurors in the highest court of the state in which the federal court resided. ${ }^{37}$ When Illinois amended its laws to make women eligible for jury service, federal jury officials sought to supple-

presented his claims in state court so as to obtain ultimate Supreme Court review through normal channels.

The Court also imposed substantial evidentiary barriers to jury-discrimination claims. When defendants made detailed written allegations that racial discrimination had caused the virtual absence of blacks from petit and grand juries, state trial judges often summarily denied the claims on the ground that such allegations were not proof. It is unclear, of course, how the defendants were to prove their claims if denied a hearing at which to call witnesses and present evidence. The Supreme Court generally affirmed. See Martin v. Texas, 200 U.S. 316 (1906); Brownfield v. South Carolina, 189 U.S. 426 (1903); Tarrance v. Florida, 188 U.S. 519 (1903); Smith v. Mississippi, 162 U.S. 592 (1896). Furthermore, in cases where state courts conducted hearings and found no racial discrimination despite clear evidence to the contrary, the Court refused to grant relief unless the state court finding was so devoid of evidentiary support as to amount to a denial of due process. See, e.g., Thomas v. Texas, 212 U.S. 278 (1909).

Finally, in the 1930s the Court relaxed its evidentiary standards and reversed two state court decisions which had denied challenges to venires. Pierre v. Louisiana, 306 U.S. 354 (1939); Norris v. Alabama, 294 U.S. 587 (1935). In both cases, defendants had offered evidence of a virtual absence of blacks on juries coupled with a clear opportunity to discriminate in the selection process. The Court held that such evidence constituted a prima facie case of discrimination and that the evidence submitted by the states in each case failed to rebut defendants' presentations. The prima facie case doctrine, as it relates to cognizability, is discussed in the text at notes 104-08 infra.

31. 311 U.S. 128 (1940).

32. 100 U.S. at 308.

33. 311 U.S. at 130.

34. 311 U.S. at 130 (footnote omitted).

35. 315 U.S. 60 (1942).

36. The Court's opinion might be viewed as resting upon statutory rather than constitutional grounds since the selection procedure might have failed the Illinois requirement and would then have failed the federal statutory requirement. But the constitutional nature of the challenge, as well as the tone of the opinion, suggest that the sixth amendment at least strongly influenced the Court and was probably the principal source of its opinion. See 315 U.S. at 8487. A recent case seems to support this sixth amendment interpretation. See Taylor v. Louisiana, 419 U.S. 522, 527 (1975).

37. 315 U.S. at 64 . 
ment their rolls with qualified women. Glasser alleged that the women added to the rolls were drawn exclusively from a list furnished by the Illinois League of Women Voters and prepared solely from its membership. He further alleged that the women on the list had attended "jury classes whose lecturers presented the views of the prosecution." 38

The Court upheld Glasser's claim in principle, reasoning:

[Juror selection officials] must not allow the desire for competent jurors to lead them into selections which do not comport with the concept of the jury as a cross-section of the community. . . .

The deliberate selection of jurors from the membership of particular private organizations definitely does not conform to the traditional requirements of a jury trial .... [T] he dangers inherent in such a method of selection are the more real when the members of those organizations from training or otherwise acquire a bias in favor of the prosecution. The jury selected from the membership of such an organization is then not only the organ of a special class, but, in addition, it is also openly partisan. ${ }^{39}$

The Court ultimately denied Glasser's claim on the ground that he had not offered sufficient evidence in support of his allegations. ${ }^{40}$ The decision nonetheless reaffirmed the necessity of an impartial jury and clearly recognized that racial and ethnic groups are not the only significant components of a representative cross section.

In Thiel v. Southern Pacific Co., ${ }^{41}$ the Court, pursuant to its supervisory power over the administration of justice in federal courts, identified additional cognizable groups. The plaintiff, suing for damages in a federal diversity case, moved to strike the jury venire on the ground that lower-class working people had been systematically excluded and that only businessmen and others inclined toward the employer's viewpoint were, therefore, on the rolls. ${ }^{42} \mathrm{~A}$ hearing on the motion revealed that jury officials deliberately excluded from the rolls everyone who worked for a daily wage. The Court held that this practice failed to satisfy the principles of jury selection:

The American tradition of trial by jury, considered in connection with either criminal or civil proceedings, necessarily contemplates an impartial jury drawn from a cross-section of the community. Smith $v$. Texas ... ; Glasser $v$. United States .... This does not mean, of

38. 315 U.S. at 84.

39. 315 U.S. at 86.

40. See 315 U.S. at 87.

41. 328 U.S. 217 (1946).

42. Thiel, a passenger, had jumped out of the window of a moving train operated by the Southern Pacific Company. He sought to recover damages on the ground that railroad employees were negligent in failing to keep safe a passenger so clearly "out of his normal mind." 328 U.S. at $218-19$. 
course, that every jury must contain representatives of all the economic, social, religious, racial, political and geographic groups of the community; frequently such complete representation would be impossible. But it does mean that prospective jurors shall be selected by court officials without systematic and intentional exclusion of any of these groups. Recognition must be given to the fact that those eligible for jury service are to be found in every stratum of society. Jury competence is an individual rather than a group or class matter. That fact lies at the very heart of the jury system. To disregard it is to open the door to class distinctions and discriminations which are abhorrent to the democratic ideals of trial by jury. ${ }^{43}$

Thiel is the Court's most expansive treatment of cognizability. The Court assumed that a broad range of groups are distinct and identifiable, and that members of each share attitudes and experiences which may not be adequately represented if they are excluded from service. The Court did not require proof that the exclusion of wage earners prejudiced Thiel. The mere danger of such prejudice justified the Court, in the exercise of its supervisory powers, in ordering a new trial by a jury fairly chosen.

The Court's expansive approach continued in Ballard $v$. United States, ${ }^{44}$ which involved a challenge to the intentional and systematic exclusion of women from the grand and petit jury rolls in the Southern District of California. In sustaining the challenge, the Court assumed that women are a cognizable group, without requiring proof that women share attitudes or perspectives different from men's:

It is said ... that an all male panel drawn from the various groups within a community will be as truly representative as if women were included. The thought is that the factors which tend to influence the action of women are the same as those which influence the action of men-personality, background, economic status-and not sex. Yet it is not enough to say that women when sitting as jurors neither act nor tend to act as a class. Men likewise do not act as a class. But, if the shoe were on the other foot, who would claim that a jury was truly representative of the community if all men were intentionally and systematically excluded from the panel? The truth is that the two sexes are not fungible; a community made up exclusively of one is different from a community composed of both; the subtle interplay of influence one on the other is among the imponderables. To insulate the courtroom from either may not in a given case make an iota of difference. Yet a flavor, a distinct quality is lost if either sex is excluded. The exclusion of one may indeed make the jury less representative of the

43. 328 U.S. at 220.

44. 329 U.S. 187 (1946). 
community than would be true if an economic or racial group were excluded. ${ }^{45}$

The Court also stated that the defendants' claim did not depend on a showing of prejudice in the individual case, because " $[t]$ he injury is not limited to the defendant-there is injury to the jury system, to the law as an institution, to the community at large, and to the democratic ideal reflected in the processes of our courts." 46 Again acting in the exercise of its federal supervisory powers, the Court overturned the convictions.

Any hope that the standards enunciated in the 1940s would usher in an era of representative juries dimmed when the Court next considered cognizability in 1954. Hernandez $v$. Texas ${ }^{47}$ signalled a change in approach. Hernandez was indicted for murder and convicted in Jackson County, Texas. He alleged that Mexican-Americans were systematically excluded from service as grand and petit jurors in the county, thus depriving him of the equal protection of the laws. Since he established a prima facie case of discrimination which the state was unable to rebut, the Court reversed his conviction. In considering his claim, however, the Court articulated new criteria of cognizability:

Throughout our history differences in race and color have defined easily identifiable groups which have at times required the aid of the courts in securing equal treatment under the laws. But community prejudices are not static, and from time to time other differences from the community norm may define other groups which need the same protection. Whether such a group exists within a community is a question of fact. When the existence of a distinct class is demonstrated, and it is further shown that the laws, as written or as applied, single out that class for different treatment not based on some reasonable classifica-

45. 329 U.S. at 193-94 (footnote omitted).

46. 329 U.S. at 195. In Peters v. Kiff, 407 U.S. 493 (1972), there was no majority opinion, but three justices elaborated on the interests protected by representative juries (opinion of Marshall, J., joined by Douglas and Stewart, JJ.). In Peters, a white defendant challenged the systematic exclusion of blacks from grand and petit juries in Muscogee County, Georgia. The state argued that the defendant was not prejudiced by the exclusion, but the Court concluded that the argument took "too narrow a view of the kinds of harm that flow from discrimination in jury selection." 407 U.S. at 498 . It stated that "the exclusion from jury service of a substantial and identifiable class of citizens has a potential impact that is too subtle and too pervasive to admit of confinement to particular cases." 407 U.S. at 503. The Court was unwilling to assume that exclusion of blacks is relevant only to racial issues.

When any large and identifiable segment of the community is excluded from jury service, the effect is to remove from the jury room qualities of human nature and varieties of human experience, the range of which is unknown and perhaps unknowable. It is not necessary to assume that the excluded group will consistently vote as a class in order to conclude, as we do, that its exclusion deprives the jury of a perspective on human events that may have unsuspected importance in any case that may be presented.

407 U.S. at 503-04.

47. 347 U.S. 475 (1954). 
tion, the guarantees of the Constitution have been violated. ${ }^{48}$

The Court did not simply assume that Mexican-Americans were a cognizable group. Instead, it held that Hernandez had an "initial burden" of proving that "persons of Mexican descent constitute a separate class in Jackson County, distinct from 'whites." "49 The question whether this might be accomplished simply by judicial notice, the Court observed in a footnote, was not before it. ${ }^{50}$ But the Court stated that another way to establish cognizability was to show the "attitude of the community." 51 Hernandez satisfied that burden by demonstrating that the community generally distinguished between "white" and "Mexican," that Mexican-Americans were less involved than whites in business and community groups, that children of Mexican descent had recently been required to attend a segregated school, and that Mexican-Americans were discriminated against in the use of dining and public toilet facilities. ${ }^{52}$

Although Hernandez prevailed, the case marks the first potentially limiting use of the cognizability concept. To be sure, Hernandez permitted judicial notice of groups in appropriate cases. Nonetheless, the Court's opinion intimated that members of less easily identifiable groups subjected to subtler forms of community bias might have greater difficulty establishing their cognizability than in the 1940s. ${ }^{53}$ And, in the years following Hernandez, courts have become increasingly reluctant to find groups cognizable. Women and various racial, ethnic, and religious groups have met with the most success, while occupational, income, and geographical groups, and groups defined by education or age generally have not been recognized.

After Ballard, courts assumed that women were a cognizable

48. 347 U.S. at 478.

49. 347 U.S. at 479 (footnote omitted).

50. 347 U.S. at 479 n.9.

51. 347 U.S. at 479.

52. 347 U.S. at $479-80$.

53. Although Hernandez is often interpreted as establishing more stringent proof requirements, in the case itself, cognizability enlarged, not limited, the cross-sectional right. When the Court said that community prejudices were not static and that, at different times, different groups might need the aid of the courts in securing equal treatment, 347 U.S. at 478 , it was responding to the view that only blacks are protected by the equal protection clause. In finding that plaintiffs had convincingly shown that Mexican-Americans were a separate class in Jackson County, distinct from whites, 347 U.S. at 479, the Court hardly meant to require such complete proof for every equal protection challenge, since it expressly reserved the question whether the cognizability of Mexican-Americans might have been judicially noticed. 347 U.S. at $479 \mathrm{n} .9$. Both the explicit language and the tenor of the opinion suggest that the Court viewed the identifiability "requirement" as expanding, not limiting, the equal protection guarantee. If this suggestion is true, Hernandez should not be interpreted as imposing rigorous proof requirements where none previously existed. 
group, ${ }^{54}$ and condemned their intentional exclusion from juries. ${ }^{55}$ Until recently, however, states were allowed to grant women blanket exemptions solely because of their sex or could even make registration for jury duty a prerequisite of service for women but not for men. ${ }^{56}$ In 1975, Taylor v. Louisiana ${ }^{57}$ firmly rejected such discriminations. The Court held that the sixth amendment was violated by a state law which permitted women to serve on juries only if they had previously declared their interest in jury service and which resulted in the complete exclusion of women from the venire.

Taylor is particularly important because it relies on the sixth amendment. Although the Court had previously held that the sixth amendment was binding upon the states by virtue of the fourteenth amendment, ${ }^{58}$ Taylor established for the first time that "the selection of a petit jury from a representative cross section of the community is an essential component of the Sixth Amendment right to a jury trial."59 In reaching this conclusion, the Court found "instructive" its prior cases involving the equal protection clause and the exercise of supervisory powers over federal trials, ${ }^{60}$ and it reaffirmed some of the policies supporting the requirement of a fair cross section:

The purpose of a jury is to guard against the exercise of arbitrary power-to make available the commonsense judgment of the community as a hedge against the overzealous or mistaken prosecutor and in preference to the professional or perhaps overconditioned or biased response of a judge. . . . This prophylactic vehicle is not provided if the jury pool is made up of only special segments of the populace or if large, distinctive groups are excluded from the pool. Community participation in the administration of the criminal law, moreover, is not only consistent with our democratic heritage but is also critical to public confidence in the fairness of the criminal justice system. Restricting

54. See, e.g., United States v. Zirpolo, 450 F.2d 424 (3d Cir. 1971); Ford v. White, 430 F.2d 951, 955 (5th Cir. 1970); United States v. Butera, 420 F.2d 564, 571 (1st Cir. 1970); United States v. DiTommaso, 405 F.2d 385, 391 (4th Cir. 1968), cert. denied, 394 U.S. 934 (1969).

55. See United States v. Zirpolo, 450 F.2d 424, 428 (3d Cir. 1971); Abbott v. Mines, 411 F.2d 353, 355 (6th Cir. 1969); Mayfield v. Steed, 345 F. Supp. 806, 808 (E.D. Ark. 1972), affd. per curiam, 473 F.2d 691 (8th Cir. 1973); White v. Crook, 251 F. Supp. 401, 408 (M.D. Ala. 1966).

56. In Hoyt v. Florida, 368 U.S. 57 (1961), for example, the Supreme Court approved a statute which provided that "the name of no female person shall be taken for jury service unless said person has registered with the clerk of the circuit court her desire to be placed on the jury list." 368 U.S. at 58. Noting that the law "does not purport to exclude women from state jury service," 368 U.S. at 60 , the Court found the statute to be based on a reasonable classification since "woman is still regarded as the center of home and family life." 368 U.S. at 62 .

57. 419 U.S. 522 (1975).

58. Duncan v. Louisiana, 391 U.S. 145 (1968).

59. 419 U.S. at 528.

60. 419 U.S. at 526-28. 
jury service to only special groups or excluding identifiable segments playing major roles in the community cannot be squared with the constitutional concept of jury trial. ${ }^{61}$

Applying these principles, the Court found that women are "sufficiently numerous and distinct from men," i.e., that they are cognizable. ${ }^{62}$ It concluded that, as in Ballard, the systematic exclusion of women rendered the jury less representative in a subtle but substantial way and violated the fair-cross-section requirement. ${ }^{63}$ The Court conceded that an earlier case, Hoyt v. Florida, ${ }^{64}$ had held that a similar discrimination did not violate the due process or equal protection guarantees since the state interest in preserving a distinct societal role for women was a sufficiently rational basis for the exclusion. ${ }^{65}$

But Hoyt did not involve a defendant's Sixth Amendment right to a jury drawn from a fair cross section of the community. . . . The right to a proper jury cannot be overcome on merely rational grounds. There must be weightier reasons if a distinctive class representing 53\% of the eligible jurors is for all practical purposes to be excluded from jury service. ${ }^{66}$

This passage suggests that Taylor established a broader cross-sectional right under the sixth amendment than under the equal protection clause. On the other hand, the Court may simply have been searching for some facially plausible ground for distinguishing $H o y t$. It remains to be seen whether Taylor will be interpreted as broadening the concept of cognizability in sixth amendment cases.

\section{B. Different Approaches to the Cognizability of Particular Groups}

Courts have often simply taken judicial notice of the cognizability of racial, ethnic, and religious groups. For example, courts have assumed the cognizability of Indians in Mellette County, South Dakota;67 of Mexican-Americans in Logan County, Colorado; ${ }^{68}$ of Puerto Ricans in St. Croix, Virgin Islands, ${ }^{69}$ and of non-

61. 419 U.S. at 530.

62. 419 U.S. at 531.

63. 419 U.S. at 530. The Court was impressed with evidence that "women bring to juries their own perspectives and values that influence both jury deliberation and result." 419 U.S. at 532 n.12.

64. 368 U.S. 57 (1961).

65. 419 U.S. at 533-34. See note 56 supra.

66. 419 U.S. at 534.

67. State v. Plenty Horse, 85 S.D. 401,184 N.W.2d 654 (1971).

68. Montoya v. People, 141 Colo. 9, 345 P.2d 1062 (1959).

69. United States ex rel. Leguillo v. Davis, 115 F. Supp. 392, 398 (D.V.I. 1953), revd. on other grounds, 212 F.2d 681 (3d Cir. 1954). 
Caucasians in Hawaii. ${ }^{70}$ Similarly, the opinion in Quadra v. Superior Court" $^{71}$ assumed that racial groups are cognizable "under judicial notice of obvious sociological facts throughout this nation."72 With respect to religious groups, some courts have stated without discussion that Jews, ${ }^{73}$ Catholics, ${ }^{74}$ and persons who do not believe in a supreme being ${ }^{75}$ are cognizable.

In United States v. DeAlba-Conrado, ${ }^{76}$ on the other hand, the court remanded the case for a hearing on whether Latin-Americans constitute a cognizable group in Miami, Florida. ${ }^{77}$ And in Quadra, although the court expressed little doubt "that persons of LatinAmerican descent and of Chinese and Japanese ethnic origin are identifiable groups within San Francisco,"78 it refrained from deciding whether to take judicial notice of their cognizability or to require plaintiffs to submit proof at a later hearing. ${ }^{79}$ Finally, in Grech $v$. Wainwright, ${ }^{80}$ the court stated that proof of cognizability of members of the Jewish faith in the geographical areas from which the jury was drawn was critical to the constitutional claim of jury exclusion. ${ }^{81}$

Courts generally have held occupational groups cognizable where the discrimination was similar to that proscribed in Thiel. For example, People v. White 82 assumed the cognizability of "hourly

70. United States v. Fujimoto, 105 F. Supp. 727 (D. Hawaii 1952). In State v. Lopez, 182 Kan. 46, 318 P.2d 662 (1957), the court assumed that Mexican-Americans generally are a cognizable group. The Court declined to find them cognizable in Geary County, Kansas, however, because defendant was unable to establish that this ethnic group made up a significant portion of the community. The 1950 census figures revealed that of a total population of 21,671, only 92 were of "other races." The Court concluded that "the Mexican population, if any, in Geary County was not large enough to raise a presumption of systematic exclusion from jury service." $182 \mathrm{Kan}$. at 51, $318 \mathrm{P} .2 \mathrm{~d}$ at 665.

71. 378 F. Supp. 605 (N.D. Cal. 1974).

72. 378 F. Supp. at 618 n.19.

73. Schowgurow v. State, 240 Md. 121, 213 A.2d 475 (1965). See also State v. Madison, 240 Md. 265, 213 A.2d 880 (1965).

74. United States v. Suskin, 450 F.2d 596, 599 (2d Cir. 1971).

75. Juarez v. State, 102 Tex. Crim. 297, 277 S.W. 1091 (1925).

76. 481 F.2d 1266 (5th Cir. 1973).

77. 481 F.2d at 1270 n.7.

78. 378 F. Supp. at 618 n. 19 .

79. 378 F. Supp. at 618 n.19. Castaneda v. Partida, 430 U.S. 482, 495 (1977), and Muniz v. Beto, 434 F.2d 697, 701 (5th Cir. 1970), found that the defendants had submitted adequate proof of the cognizability of Mexican-Americans in the Texas counties of Hidalgo and El Paso, respectively. Similarly, State v. Villafane, 164 Conn. 637, 645, 325 A.2d 251, 256 (1973), found that the record established the cognizability of Puerto Ricans in Fairfield County, Connecticut. 80. 492 F.2d 747 (5th Cir. 1974).

81. 492 F.2d at 749 n.3.

82. 43 Cal. 2d 740, 278 P.2d 9 (1954) (en banc). 
wage earners and those of less fortunate economic circumstances" 83 in condemning the selection of jurors from lists of local clubs and associations whose members, for the most part, were well-to-do businessmen. ${ }^{84}$ Similarly, Simmons $v$. State ${ }^{85}$ assumed the cognizability of "common laborers" in barring their intentional, systematic exclusion from the jury rolls in Aluchua County; Florida. ${ }^{86}$

In other cases, however, courts have refused to recognize occupational or income groups because the group in question was inadequately defined or because proof of community attitudes toward the group was lacking. In Quadra, for example, plaintiffs challenged the underrepresentation of low-income blue-collar workers. The court dismissed the claim because the plaintiffs had made "virtually no effort to define this class as a distinct, identifiable group in the community." 87 The Court held that the plaintiffs had not drawn a rational line between blue-collar and white-collar workers and that the low-income class they attempted to construct was "too imprecise and undoubtedly over-inclusive" given the relatively high wages paid many workers in craft occupations. ${ }^{88}$ Finally, the plaintiffs had failed to allege facts pertaining to community attitudes which would "give some content" to the group. ${ }^{89}$

Similarly, United States v. McDaniels ${ }^{90}$ refused to recognize either the poor or food-stamp recipients as cognizable under the federal Jury Selection and Service Act. ${ }^{91}$ The Court stressed that any line dividing the poor from the affluent is inherently arbitrary, since "there is no national standard of who is poor and who is not poor."92 The Court also noted that one's economic status may change from

83. 43 Cal. $2 d$ at 753,278 P.2d at 17.

84. The Court ultimately denied relief on the ground that all occupational and income groups seemed adequately represented on the actual venire of 525 persons from which the jury was chosen. $43 \mathrm{Cal} .2 \mathrm{~d}$ at $753,278 \mathrm{P} .2 \mathrm{~d}$ at 17.

85. 182 So. 2d 442 (Dist. Ct. App. Fla. 1966).

86. See also Labat v. Bennett, 365 F.2d 698, 713-14, 719-24 (5th Cir. 1966) (en banc), cert. denied, 386 U.S. 991 (1967) (court assumed cognizability of daily wage earners, a group comprised of manual laborers and outside workers).

87. 378 F. Supp. at 621.

88. $378 \mathrm{~F}$. Supp. at 621. The Census Bureau's categorization of occupational titles is useful in solving this problem. The system developed from the 1970 census consists of 441 specific occupation categories arranged into 12 major occupation groups. Information on the composition of the detailed categories is given in U.S. BUREAU of THE Census, 1970 Census of Population, Classified Index of Industries and Occupations (1971).

89. 378 F. Supp. at 621. See also People v. Navarette, 54 Cal. App. 3d 1064, 1077, 127 Cal. Rptr. 55, 63-64, (1976).

90. 370 F. Supp. 298 (E.D. La. 1973).

91. 28 U.S.C. $\S \S 1861-74$ (1976).

92. 370 F. Supp. at 307. 
year to year and that "the elusiveness of the concept [of poverty] and the changes in purchasing power of money make the use of such a classification difficult."93 Finally, since no proof was submitted that food-stamp recipients share attitudes or opinions different from those of other groups, the Court found the classification meaningless for jury selection purposes. ${ }^{94}$

Similar reasoning also may underlie the reluctance of courts to consider educational groups cognizable. Many courts have stressed the absence of proof that the uneducated share distinct attitudes or characteristics which set them apart from the rest of society and which cannot be adequately represented by the educated. ${ }^{95}$ The view that the uneducated are not necessary to a representative cross section also may stem from the belief that juries perform better without them. Thus, courts have uniformly approved minimum educational requirements for jurors. ${ }^{96}$

Many of the expansive earlier pronouncements on cognizability involved the Supreme Court's exercise of its supervisory powers over federal trials. Although these early decisions generally relied little upon the language of the applicable federal statute, ${ }^{97}$ the passage of the Jury Selection and Service Act ${ }^{98}$ in 1968 gave federal courts more explicit guidance for determining cognizability. The Act declared it to be federal policy "that all litigants in federal courts enti-

93. 370 F. Supp. at 308.

94. See also United States v. Kleifgen, 557 F.2d I293, 1296 (9th Cir. 1977).

95. E.g., United States v. Kleifgen, 557 F.2d 1293, 1296 (9th Cir. 1977); United States v. Potter, 552 F.2d 901, 905 (9th Cir. 1977). United States v. Butera, 420 F.2d 564 (1st Cir. 1970), recognized such a group. The Court noted the difficulty in defining precisely a less educated group, but held that "the less educated are a sufficiently large group with sufficiently distinct views and attitudes that its diluted presence on the actual jury pools requires explanation." $420 \mathrm{~F} .2 \mathrm{~d}$ at 571.

96. See, e.g., Carter v. Jury Commn., 396 U.S. 320, 332 (1970); Gibson v. Mississippi, 162 U.S. 565, 589 (1896); Strauder v. West Virginia, 100 U.S. 303, 310 (1879).

Courts also have refused to hold geographical groups cognizable. Although such groups are relatively easy to define, United States v. Bryant, 291 F. Supp. 542, 551 (D. Me. 1968), complainants normally have been unable to demonstrate that people in different parts of a district have significantly different attitudes or that there is likely to be bias in the absence of a residential cross section. See, e.g., Cobbs v. Robinson, 528 F.2d 1331, 1336 (2d Cir. 1975), cert. denied, 424 U.S. 947 (1976); United States v. Butera, 420 F.2d 564, 572 (1st Cir. 1970); Quadra v. Superior Court, 378 F. Supp. 605, 619-21 (N.D. Cal. 1974); State v. Townsend, 167 Conn. 539, 548-50, 356 A.2d 125, 132-34 (1975), cert. denied, 423 U.S. 846 (1975); People v. Chesler, 91 Misc. 2d 551, 557, 398 N.Y.S.2d 320, 324 (Sup. Ct. 1977). If discrimination by residence results in underrepresentation of other identifiable groups, a designation of residential cognizability might be a convenient way to alleviate that problem. In most instances, however, it is easier to address underrepresentation of other groups directly.

97. The earlier federal statute gave almost no guidance to federal courts, since it simply incorporated state standards. Judicial Code, ch. 231, $\$ \S 275-278,36$ Stat. 1164, 1165 (1911).

98. Jury Selection and Service Act of 1968, Pub. L. No. 90-274, 82 Stat. 53 (codified at $\S \S 101-04,28$ U.S.C. $\$ \S 1861-74$ (1976)). 
tled to trial by jury shall have the right to grand and petit juries selected at random from a fair cross section of the community . . ."99 and that "[n]o citizen shall be excluded from [federal jury] service . . . on account of race, color, religion, sex, national origin, or economic status." 100 Courts have generally interpreted these provisions as stricter than the constitutional fair-cross-sectional requirement and have held that compliance with the statute constitutes compliance with the Constitution. ${ }^{101}$ And its procedural specificity and breadth of purpose have encouraged courts to employ the statute rather than the vaguer supervisory power as the standard for jury challenges in federal courts. ${ }^{102}$ Nevertheless, reliance on the federal statute has not led courts to interpret cognizability much more generously than in constitutional cases. ${ }^{103}$

\section{Possible Explanations of the Conflicting Lines of Authority}

It is difficult to harmonize the divergent and often conflicting lines of authority interpreting the cross-sectional ideal. In some cases, courts have freely taken judicial notice that a group is cognizable. In others, they have required proof of cognizability and been sensitive to line-drawing problems. A number of factors may explain these differences in approach, especially the recent reluctance of the courts either to extend the list of groups considered cognizable or even to recognize groups previously considered identifiable. An examination of these factors, however, suggests that none of them provides a valid basis for that reluctance.

The first possible explanation for the divergent judicial approaches and outcomes is that they may vary according to the nature of the proof offered to support or refute the claim of discrimination. In Thiel and similar cases, in which challenges to juries were sustained, the defendants explicitly admitted there had been intentional or systematic exclusion of persons in specific occupations or social strata. But in cases such as Quadra and McDaniels, in which challenges failed, those challenging selection procedures had had to rely on the prima facie case doctrine. Since its first application in $1935,{ }^{104}$ that doctrine has been a formidable weapon in challenges to

99. 28 U.S.C. $\$ 1861$ (1976).

100. 28 U.S.C. $\S 1862$ (1976).

101. See, e.g., United States v. Test, 550 F.2d 577, 584 (10th Cir. 1976); United States v. Guzman, 337 F. Supp. 140, 142-43 (S.D.N.Y.), affd., 468 F.2d 1245 (2d Cir. 1972), cert. denied, 410 U.S. 937 (1973).

102. See United States v. Butera, 420 F.2d 564, 574-75 (1st Cir. 1970).

103. See, e.g., United States v. Test, 550 F.2d 577, 585-86 (10th Cir. 1976).

104. See Norris v. Alabama, 294 U.S. 587 (1935), discussed in note 30 supra. 
unrepresentative juries. But the very strength of the doctrine may have worked to undermine it. Courts may fear that if they find many occupational and income groups cognizable, the presence and effectiveness of the doctrine may inspire innumerable challenges to jury selection procedures.

The prima facie case doctrine offers plaintiffs several advantages over traditional modes of proof. First, direct proof of discrimination is not required. A showing of significant disparities between the composition of the jury rolls and the composition of the community, coupled with a showing that jury officials had an opportunity to discriminate in the selection process, establishes a prima facie case and shifts the burden to jury officials to prove that the disparities resulted from something other than discrimination. ${ }^{105}$ Since mere affirmations of good faith are not a sufficient rebuttal, ${ }^{106}$ jury officials often are hard pressed to sustain their burden. Second, the challenger defines the class. In cases of admitted, intentional discrimination, jury officials "define" the excluded group by their statements and actions. In a prima facie case, by contrast, a broader range of challenges normally is plausible since jury rolls in most jurisdictions underrepresent blacks, various ethnic groups, women, the young, the old, the uneducated, the poor, and many occupational groups. ${ }^{107}$

Of course, courts can regulate the use of the prima facie case doctrine by declining to hold the groups in question cognizable. Concern about abuse of the doctrine, however, does not justify a narrow interpretation of cognizability. Abuse could more effectively be minimized by requiring that a greater disparity be shown to establish a prima facie case or by easing the defendant's burden on rebuttal. Limiting cognizability is clumsy and perpetuates unrepresentative juries. ${ }^{108}$

The second reason for courts' reluctance to hold groups cognizable may be their confusion of the concepts of cognizability and suspectness. Both concepts protect identifiable groups from discrimination, but the similarity ends there. To say, for example, that legislative or administrative classifications based on socioeconomic status are suspect means that all such governmental classifica-

105. Castaneda v. Partida, 430 U.S. 482, 494-95 (1977); Alexander v. Louisiana, 405 U.S. $625,630-32$ (1972).

106. Castaneda v. Partida, 430 U.S. 482,498 n.19 (1977); Alexander v. Louisiana, 405 U.S. 625,632 (1972).

107. See J. VAN DYKE, supra note 4, at 291-371 apps. F-I.

108. Of course, any new restriction on the prima facie case doctrine might perpetuate unrepresentative juries. But cognizability is a particularly unfortunate kind of restriction since it entirely insulates discrimination against certain classes from any judicial protection. 
tions are subject to strict equal protection scrutiny and will fall unless the government can show that they are necessary to promote a compelling state interest. As Justice Marshall noted in his dissent to Massachusetts Board of Retirement v. Murgia: ${ }^{109}$

If a statute is subject to strict scrutiny, the statute always, or nearly always, . . . is struck down. . . . It should be no surprise, then, that the Court is hesitant to expand the . . classes subject to strict scrutiny, when each expansion involves the invalidation of virtually every classification bearing upon a newly covered category. ${ }^{110}$

To say, on the other hand, that low-income people are a cognizable group has a much more limited effect. It merely means that they may not be discriminated against in jury selection. This difference in consequence probably explains why women and racial, ethnic, and religious groups, and on occasion, age, occupational, income and educational groups, have been held cognizable for jury selection purposes, while the only suspect classifications are those based on race, alienage, or national origin. ${ }^{111}$

The courts have not applied the traditional two-tier model of equal protection analysis to jury selection cases, ${ }^{112}$ perhaps because the concepts of cognizability and suspectness serve such different purposes or perhaps because of the awkwardness of that model. Instead, courts have apparently held that discrimination against a cognizable group is simply impermissible, but that discrimination against a group which does not fully satisfy the cognizability criteria, while perhaps undesirable, is not sufficiently important to merit judicial intervention. It seems unlikely that courts will apply the two-tier model in this area. Although theoretically applicable, it does not materially aid the evaluation or resolution of jury discrimination claims, and it would have implications outside the jury area that courts may wish to avoid. ${ }^{113}$

109. 427 U.S. 307 (1976).

110. 427 U.S. at 319 (footnote omitted).

111. See generally Frontiero v. Richardson, 411 U.S. 677 (1973); San Antonio Independent School Dist. v. Rodriguez, 411 U.S. I, 17-29 (1973); Graham v. Richardson, 403 U.S. 365, 37072 (1971); Dandridge v. Williams, 397 U.S. 471, $485-86$ (1970); Loving v. Virginia, 388 U.S. 1, 8-12 (1967); Oyama v. California, 332 U.S. 633, 644-47 (1948).

112. See, e.g., Quadra v. Superior Court, 378 F. Supp. 605, 616 n.15 (N.D. Cal. 1974).

113. The two-tier model could theoretically be applied by holding that discrimination against a cognizable group can be justified only by showing that it is necessary to promote a compelling governmental interest, while discrimination against a noncognizable group need only have a rational basis. On this approach, however, a designation of cognizability amounts to a finding that the group is suspect for jury selection purposes. Such a finding might be viewed as a first step toward expanding the list of suspect classifications, something the present Court seems disinclined to do. See Frontiero v. Richardson, 411 U.S. 677 (1973) (only four Justices agree that sex is a suspect class); San Antonio Independent School Dist. v. Rodriguez, 411 U.S. 1 (1973) (wealth discriminations do not involve a suspect class); Massachusetts. Bd. of 
Finally, the divergent lines of authority may be partly accounted for by the fact that the cross-sectional right has several sources. These include the sixth amendment, the equal protection clause of the fourteenth amendment, and in federal courts, the Jury Selection and Service Act of 1968. In addition, the Supreme Court, in the exercise of its supervisory power over the federal courts, has required that juries be composed of a fair cross section. The courts have not explicitly stated that either the scope of cognizability or the kind or quantum of proof required to establish a cognizable group varies depending upon the source of the right. Nonetheless, there is some evidence that such variations exist.

It is true that, to date, courts have treated cognizability in much the same manner in sixth amendment and equal protection cases. This is not surprising, since the interests protected are often coextensive. In Strauder v. West Virginia, ${ }^{14}$ an equal protection case, the court noted that racial discrimination in jury selection endangers the defendant's right to a fair trial ${ }^{115}$ and denies members of the excluded class the right to participate equally in the administration of justice. ${ }^{116}$ Smith v. Texas, ${ }^{117}$ also an equal protection case, stressed that a representative jury is important to "the use of juries as instruments of public justice"118 and that exclusion of otherwise qualified groups "is at war with our basic concepts of a democratic society and a representative government."119 Hernandez v. Texas ${ }^{120}$ held that

Retirement v. Murgia, 427 U.S. 307 (1976) (per curiam) (age is not a suspect classification). If, on the other hand, discrimination against cognizable (but nonsuspect) groups is evaluated only under the rational-basis test, the discrimination would doubtless be justified on the ground of administrative convenience, and dismissal of the complaint would almost inevitably follow.

This latter injustice might be eased by applying an intermediate equal protection test, see generally L. TRIBE, AMERICAN CONSTITUTIONAL LAW $\$$ 16-30, 16-31 (1978), to jury discrimination against cognizable (but nonsuspect) groups. The state practice would be upheld if it substantially furthered an important governmental interest; administrative convenience would be an insufficient justification. The Court has endorsed the general use of this test for gender classifications, Craig v. Boren, 429 U.S. 190, 197 (1976), and four of the five members of the Court who addressed the constitutional issue in University of California Bd. of Regents v. Bakke, 98 S. Ct. 2733, 2783-2785 (1978) (Brennan, J., dissenting), would apply the test to benign racial preferences. Such a test perhaps is appropriate here. While not "suspect," cognizable groups are by definition important segments of the community. Their total (or partial) exclusion from juries implicates both the defendant's significant interest in an unbiased and fair-cross-sectional jury and society's vital interest in preserving the democratic ideal of the jury. An intermediate test might help reconcile theory with result in the jury discrimination area. However, if the Court is unwilling to employ this standard, the two-tier equal protection model seems wholly inapposite to jury discrimination claims.

114. 100 U.S. 303 (1879).

115. 100 U.S. at 309.

116. 100 U.S. at 308.

117. 311 U.S. 128 (1940).

118. 311 U.S. at 130.

119. 311 U.S. at 130.

120. 347 U.S. 475 (1954). 
when distinct groups are singled out for different treatment without justification, the equal protection clause is violated. ${ }^{121}$ The broad language of Hernandez clearly encompasses the interests of both a defendant who is a member of the excluded group and of other group members as well.

Cases relying on the sixth amendment stress the same interests as the equal protection cases. Glasser $v$. United States, ${ }^{122}$ which appears to be based on the sixth amendment, ${ }^{123}$ emphasized the defendant's right to a jury which is not biased in favor of the prosecution. ${ }^{124}$ It also condemned a jury that is "the organ of a special class" as incompatible with traditional democratic ideals. ${ }^{125}$ Taylor $v$. Louisiana, ${ }^{126}$ which explicitly relies on the sixth amendment, cites the defendant's interest in an unbiased jury and the value of full community participation in the administration of criminal law as the interests protected by a fully representative jury. ${ }^{127}$ Thus, since designations of cognizability serve essentially the same interests whether the source of the cross-sectional right is the equal protection clause or the sixth amendment, the courts have properly used the cases based on these two constitutional provisions interchangeably for cognizability purposes. ${ }^{128}$

A difference in approaches to cognizability is observable, however, between cases involving the exercise of the Supreme Court's

121. 347 U.S. at 478.

122. 315 U.S. 60 (1942).

123. See note 36 supra.

124. 315 U.S. at 86.

125. 315 U.S. at 86.

126. 419 U.S. 522 (1975).

127. 419 U.S. at 530-31.

128. As noted earlier, one passage in Taylor does imply that there is a broader cross-sectional right under the sixth amendment than under the equal protection clause. See text at notes 63-66 supra. But the Court was attempting to distinguish Hoyt v. Florida, 368 U.S. 57 (1961), a case it was effectively overruling. Thus, the Court's discussion should not be interpreted too liberally.

Of course, the sixth amendment and the equal protection clause do not apply coextensively to all jury discrimination claims. By its terms, the sixth amendment only applies to criminal juries, and even then only to petit juries. Although the fifth amendment's grand jury requirement might entail a fair-cross-sectional right in federal grand juries, see Castaneda v. Partida, 430 U.S. 482, 509-10 (1977) (Powell, J., dissenting), that fifth amendment requirement has not yet been applied to the states. See Hurtado v. California, 110 U.S. 516 (1884). Thus it appears that state grand jury and civil jury selection procedures are governed only by the equal protection clause. Moreover, the different nature of the injuries has created somewhat different standing doctrines in sixth amendment and equal protection cases. Although a criminal defendant who does not belong to the excluded class has standing in both types of cases, Taylor v. Louisiana, 419 U.S. 522, 526 (1975); Peters v. Kiff, 407 U.S. 493 (1972), a member of the excluded class has standing to raise only an equal protection claim, Carter v. Jury Commn., 396 U.S. 320 (1970), not a sixth amendment claim. 
supervisory power over the federal courts, and cases involving constitutional rights. Thiel v. Southern Pacific Co. ${ }^{129}$ and Ballard v. United States, ${ }^{130}$ which contain the Supreme Court's most expansive treatments of cognizability, both rested on the supervisory power. In Thiel, the Court took judicial notice that a broad range of groups are cognizable, ${ }^{131}$ and it did not require proof that Thiel was prejudiced by the exclusion of daily wage earners from his jury. Similarly, the Court in Ballard needed no proof that women share attitudes or perspectives different from men; rather, it assumed that women are a cognizable group. ${ }^{132}$ The marked difference in approach between these cases and later cases based on the Constitution may be attributable to the source of the right. Comity and cautious constitutional interpretation might explain the more conservative approach to cognizability displayed in the later cases.

By its requirement that "[n]o citizen shall be excluded from [federal jury] service ... on account of race, color, religion, sex, national origin, or economic status," 133 the federal Jury Selection and Service Act of 1968 apparently adopted the approach to cognizability of the federal supervisory power cases. The statute, however, has not led courts to interpret cognizability more liberally than in constitutional cases. ${ }^{134}$ This conservatism is not easily explained. To be sure, not all potentially cognizable groups are protected from discrimination by section 1862 of the Act. Indeed, age groups are conspicuously absent. But courts have not interpreted that section as an exclusive enumeration of identifiable groups. ${ }^{135}$ The fair-cross-sectional right established in section 1861 amply supports a broad interpretation of cognizability. Moreover, its legislative history reveals that Congress intended to adopt the broad view of the cross-sectional right earlier expressed in Thiel and other supervisory cases. ${ }^{136}$ Thus, courts construing the federal statute should

129. 328 U.S. 217 (1946).

130. 329 U.S. 187 (1946).

131. 328 U.S. at 220.

132. 329 U.S. at 193-94.

133. Jury Selection and Service Act of $1968, \S 102,28$ U.S.C. $\S 1862$ (1976).

134. See United States v. Test, 550 F.2d 577, 591-93 (10th Cir. 1976).

135. See Gewin, supra note 14, at $820-21$. Section 1862 might be interpreted as expressing a congressional finding that the enumerated groups are cognizable, and as justifying a court in recognizing them by judicial notice. But it does not follow that courts should ignore proof that other, nonenumerated groups are cognizable.

136. During the House debate many Congressmen supported the objective of obtaining a representative cross section in jury pools. For instance, Rep. Emanuel Celler, Chairman of the House Judiciary Committee, after citing Thiel, stated: "The basic aim of S. 989, as amended, is to assure that Federal grand and petit jurors are drawn at random from a representative cross section of the community and that all qualified citizens have an opportunity to be considered 
remain faithful to the language and spirit of Thiel and should recognize all significant community social groups as cognizable.

To recapitulate Part $I$, the right to a representative jury chosen from a fair cross section of the community is based on a variety of sources, both constitutional and statutory. By analyzing the underlying purposes of the cross-sectional right, courts have identified a number of interests which it protects. These include the interest of criminal defendants and other litigants in a fair trial free from bias, the interests of members of all identifiable groups in equal participation in the administration of justice, and the interest of society as a whole in ensuring that disputes are resolved fairly.

Courts have treated cognizability quite differently over the years. After the initial cognizability finding in Strauder $v$. West Virginia, ${ }^{137}$ the courts did not discuss the issue again until the 1940s. The expansive treatment of cognizability during that era appeared to end with Hernandez $v$. Texas. ${ }^{138}$ Since then, courts often have been unwilling either to recognize formerly recognized groups or to expand the limits of groups considered cognizable. Factors underlying this unwillingness may include the courts' desire to limit the effects of the prima facie case doctrine, the courts' inability to use the equal protection clause with precision and flexibility, and the courts' failure to appreciate the differences and scope of the sources of the cross-sectional right.

\section{Cognizability as Applied to Young Adults}

Challenges to the underrepresentation of the young on juries proliferated in the late 1960s and have not abated during the 1970s. They have been largely unsuccessful. In some instances, complainants conceded at the outset that jury officials did not intentionally discriminate on the basis of age, and thus their claims failed. 139 Challenges to the periodic emptying and refilling of the jury wheel in federal districts at specified intervals of four years or less ${ }^{140}$ also have been rejected, despite the inevitable, progressive exclusion of those

for Federal jury service." 114 CoNG. REC. 3990 (1968). The Senate Committee on the Judiciary stressed that "[a] jury chosen from a representative community sample is a fundamental of our system of justice." S. REP. No. 891, 90th Cong., 1st Sess. 9 (1967).

137. 100 U.S. 303 (1879).

138. 347 U.S. 475 (1954).

139. See, e.g., Cobbs v. Robinson, 528 F.2d 1331, 1335 (2d Cir. 1975), cert. denied, 424 U.S. 947 (1976); United States v. DiTommaso, 405 F.2d 385, 387 (4th Cir. 1968), cert. denied, 394 U.S. 934 (1969). See text at note 13 supra.

140. See 28 U.S.C. $\S 1863(b)(4)$ (1976). 
aged 18-21 during each four-year cycle. ${ }^{141}$ Moreover, the use of source lists on which the young are underrepresented has generally been upheld. ${ }^{142}$ However, most challenges to the exclusion of young adults from juries have failed because courts refused to consider them cognizable. Like the recent cases concerning occupational, income, and educational groups, these decisions have emphasized problems of group definition and the failure of complainants to prove that young adults share a distinct perspective which cannot be represented adequately by others.

Fortunately, not all courts have denied the cognizability of the young. In People v. Bartlett, ${ }^{143}$ the court assumed without discussion that young adults are a sufficiently large and identifiable group to be entitled to protection from discrimination, and it condemned jury selection practices which caused a gross underrepresentation of persons aged eighteen to twenty-nine on petit jury panels. ${ }^{144}$ Similarly, in People v. Attica Brothers, ${ }^{145}$ the court assumed that students are cognizable and ordered officials to revise the jury pool upon proof that students had been systematically and intentionally excluded from jury duty. ${ }^{146}$ Other courts have recognized the cognizability of the young even more explicitly. The principal case is United States $v$. Butera. ${ }^{147}$ In holding that young adults aged twenty-one to thirtyfour are cognizable, the court stated:

[W]e [cannot] close our eyes to the contemporary national preoccupation with a "generation gap," which creates the impression that the attitudes of young adults are in some sense distinct from those of older adults. That apparent distinctness is sufficient for us to say that neither class could be excluded from jury pools without some justification. ${ }^{148}$ Another court, citing Butera, also found young adults cognizable

141. Hamling v. United States, 418 U.S. 87 (1974), approved the federal scheme on the ground that "some play in the joints of the jury-selection process is necessary in order to accommodate the practical problems of judicial administration." 418 U.S. at 138. See also United States v. Smith, 523 F.2d 771, $780-81$ (5th Cir. 1975), cert. denied, 429 U.S. 817 (1976); United States v. Ware, 473 F.2d 530, 537 (9th Cir. 1973); United States v. Ross, 468 F.2d 1213, 1218 (9th Cir. 1972), cert. denied, 410 U.S. 989 (1973); Chase v. United States, 468 F.2d 141, 145 (7th Cir. 1972).

142. See note 8 supra.

143. 89 Misc. 2d 874, 393 N.Y.S.2d 866 (Sup. Ct. 1977).

144. 89 Misc. $2 d$ at $881-83,393$ N.Y.S.2d at $871-72$.

145. 79 Misc. 2d 492, 359 N.Y.S.2d 699 (Sup. Ct. 1974).

146. 79 Misc. $2 \mathrm{~d}$ at 495,359 N.Y.S.2d at 704 . However, the court was more doubtful about the cognizability of young people. Without reaching the issue, the court ruled against complainants because they failed to prove intentional discrimination against the young. 79 Misc. $2 d$ at 495,359 N.Y.S.2d at 703.

147. 420 F.2d 564 (1st Cir. 1970).

148. 420 F.2d at 570 . Defendant's claim ultimately was rejected, however, because the court found that the key-man system under attack was reasonably designed to obtain a fair cross section for the jury pools in southern Maine, and that it was administered "without dis- 
and condemned automatic exemption of students because it caused substantial underrepresentation of young people on the jury rolls. ${ }^{149}$

Courts refusing to recognize young adults generally rely on the failure of the group to satisfy one or more of the cognizability criteria articulated in United States $\nu$. Guzman:

A group to be "cognizable" for present purposes must have a definite composition. That is, there must be some factor which defines and limits the group. A cognizable group is not one whose membership shifts from day to day or whose members can be arbitrarily selected. Secondly, the group must have cohesion. There must be a common thread which runs through the group, a basic similarity in attitudes or ideas or experience which is present in members of the group and which cannot be adequately represented if the group is excluded from the jury selection process. Finally, there must be a possibility that exclusion of the group will result in partiality or bias on the part of juries hearing cases in which group members are involved. That is, the group must have a community of interest which cannot be adequately protected by the rest of the populace. ${ }^{150}$

Thus, United States $v$. Ross ${ }^{151}$ reasoned that the refusal to hold the young cognizable was "justified in light of the fact that the parameters of such a group are difficult to ascertain, as evidenced by the widely varying ages which have been used to define it." 152 Some courts have declined to recognize age groups spanning only a few years because it was not shown that persons in the designated groups share distinct views. In United States v. Kuhn, ${ }^{153}$ for example, defendant challenged the systematic exclusion of persons aged twentyone to twenty-three from jury service. The Court held: "There is nothing identifiable or distinctive about young adults in the age range of 21 to 23 to set them apart from young adults aged 23 and

cernible discrimination against any group." $420 \mathrm{~F} .2 \mathrm{~d}$ at 574 . The court thus concluded that the government had rebutted the defendant's prima facie case. $420 \mathrm{~F} .2 \mathrm{~d}$ at $574 \mathrm{n} .24$.

149. People v. Marr, 67 Misc. 2d 113, 117, 324 N.Y.S.2d 608, 613 (Just. Ct. 1971). See also People v. Fujita, 43 Cal. App. 3d 454, 475-76, 117 Cal. Rptr. 757, 770 (1974); Julian v. State, 135 Ga. App. 592, 215 S.E.2d 496 (1975); Paciona v. Marshall, 45 App. Div. 2d 462, 359 N.Y.S.2d 360, affd., 35 N.Y.2d 289, 319 N.E.2d 199, 360 N.Y.S.2d 882 (1974); State v. Holstrom, 43 Wis. 2d 465, 470-73, 168 N.W.2d 574, 578 (1969).

150. 337 F. Supp. 140, 143-44 (S.D.N.Y.), affd., 468 F.2d 1245 (2d Cir. 1972), cert. denied, 410 U.S. 937 (1973). Employing these criteria, the court found that none of the groups described by complainants-18- to 21-year-olds, 24- to 30-year-olds, and "younger persons" in general-were cognizable. $337 \mathrm{~F}$. Supp. at 145-46.

15I. 468 F.2d 1213 (9th Cir. 1972), cert. denied, 410 U.S. 989 (1973).

152. 468 F.2d at 1217. See also Chase v. United States, 468 F.2d 141, 144 (7th Cir. 1972); Quadra v. Superior Court, 378 F. Supp. 60S, 623 (N.D. Cal. 1974); United States v. Guzman, 337 F. Supp. I40, 146 (S.D.N.Y.), affd., 468 F.2d 1245 (2d Cir. 1972), cert. denied, 410 U.S. 937 (1973).

153. 441 F.2d 179 (5th Cir. 1971). 
over who were eligible for jury duty at the time in question."154

Claims of discrimination against age groups spanning more years have often been rejected for similar failures of proof. For example, United States ex rel. Chestnut v. Criminal Court ${ }^{155}$ sustained grand jury selection procedures that operated to exclude all people under thirty-five because "[p]etitioners here have presented no factual data of any sort, tentative or otherwise, to support their suspicion of partiality" against defendants. 156 The Court also found "no apparent ground for assuming that a grand jury deficient in the various underrepresented groups would be unduly sympathetic to the prosecutor."157 Similarly, the court in Quadra v. Superior Court declined to follow Butera in taking judicial notice of cognizability; it dismissed a claim on behalf of young adults aged twenty-one to forty because plaintiffs offered no proof that the group was distinct and identifable. ${ }^{158}$ Finally, many courts denying the cognizability of the young object that inevitably there are differences as well as similarities among members of the group. ${ }^{159}$

The Supreme Court has yet to decide whether young adults are an identifiable group for jury selection purposes, ${ }^{160}$ nor has the

154. 441 F.2d at 181. Similarly, United States v. Olson, 473 F.2d 686 (8th Cir.), cert. denied, 412 U.S. 905 (1973), held that complainants failed to show that the attitudes of the 18to 20-year-old age group were inadequately represented by those several years older than they. 473 F.2d at 688. See also United States v. Ross, 468 F.2d 1213, 1217-18 (9th Cir. 1972), cerl. denied, 410 U.S. 989 (1973); United States v. Allen, 445 F.2d 849 (5th Cir. 1971); King v. United States, 346 F.2d 123 (1st Cir. 1965); United States v. Deardorff. 343 F. Supp. 1033, 1043 (S.D.N.Y. 1971); United States v. Guzman, 337 F. Supp. 140, 146 (S.D.N.Y.), affd, 468 F.2d 1245 (2d Cir. 1972), cert. denied, 410 U.S. 937 (1973). United States v. Butera, 420 F.2d 564 (1st Cir. 1970), which held young adults aged 21-34 cognizable, often is distinguished in cases reviewing two- to four-year age groups on the ground that the age group in Butera was much larger and thus more stable and identifiable. See, e.g., United States v. Ross, 468 F.2d at 1217 n.4.

155. 442 F.2d 611 (2d Cir.), cert. denied, 404 U.S. 856 (1971)

156. 442 F.2d at 616 n.9.

157. 442 F.2d at 616.

158. 378 F. Supp. 605, 622-23 (N.D. Cal. 1974). See also United States v. Diggs, 522 F.2d 1310, 1316-17 (D.C. Cir.), cert. denied, 429 U.S. 852 (1976); United States v. Briggs, 366 F. Supp. 1356, 1362 (N.D. Fla. 1973); United States v. Guzman, 337 F. Supp. 140, 145-46 (S.D.N.Y.), affd., 468 F.2d 1245 (2d Cir. 1972), cert. denied, 410 U.S. 937 (1973).

159. See, e.g., United States v. Greene, 489 F.2d 1145, 1149 (D.C. Cir. 1973), cert. denied, 419 U.S. 944 (1974); United States v. Guzman, 468 F.2d 1245, 1247 n.5 (2d Cir. 1972), cert. denied, 410 U.S. 937 (1973); United States v. Ross, 468 F.2d 1213, 1217 (9th Cir. 1972), cert. denied, 410 U.S. 989 (1973).

160. Hamling v. United States, 418 U.S. 87 (1974), assumed without reaching the issue that the young are a cognizable group and found that the petitioners had failed to establish a prima facie case of discrimination against young adults aged 18-24. 418 U.S. at 135-38. The Court did appear skeptical of their cognizability:

Petitioners do not cite case authority for the proposition that the young are an identifiable group entitled to a group-based protection under our prior cases, see [Hernandez]; claims of exclusion of the young from juries have met with little success in the federal courts.

418 U.S. at 137 (citation and footnote omitted). And the Court seemed to assume that a pur- 
Court defined precisely the general standards for determining cognizability. The criteria of cognizability set forth in Guzman are essentially those developed by the lower courts over the years. However, they should not be applied either uncritically or too stringently, as some courts have done. The first criterion of Guzman, that a group have a definite composition and not be arbitrarily defined, is troublesome. Although the criterion has some validity, ${ }^{161}$ in applying it courts often have ignored the fact that society must draw many lines which are somewhat arbitrary. The second criterion, that the group be cohesive and have basically similar attitudes, ideas, and experiences, is more acceptable. However, this criterion should not be misinterpreted as requiring complete uniformity within the group. ${ }^{162}$ As several members of the Court reasoned in Peters $v$. Kiff, "It is not necessary to assume that the excluded group will consistently vote as a class in order to conclude, as we do, that its exclusion deprives the jury of a perspective on human events that may have unsuspected importance in any case that may be presented."163

The third criterion states as a requirement that exclusion of the group might cause juries to be biased against a defendant from that group. This is a sufficient but not necessary condition of cognizability, for the Supreme Court has clearly held that defendants who do not belong to a group nonetheless have standing to object to its exclusion from the jury under both the sixth amendment ${ }^{164}$ and the equal protection clause. ${ }^{165}$ Moreover, this criterion and the sec-

poseful discrimination against the young must be shown. 418 U.S. at 137. However, the opinion offers only a very cursory discussion of the age-discrimination claim; the predominant issue before the sharply divided Court was the constitutional validity of an obscenity prosecution.

Earlier in the same term that Hamling was decided, several members of the Court were in favor of hearing a defendant's contention that women and young adults aged 18-30 were systematically and purposefully excluded from grand and petit jury venires. The defendant had asserted that proof of underrepresentation and of an opportunity to discriminate should establish a prima facie case, as in Alexander v. Louisiana, 405 U.S. 625 (1972), a racial discrimination case. The Justices responded:

Though Alexander involved racial discrimination, appellant's contention certainly presents a substantial question whether the principles of that decision should apply where any large, identifiable segment of the community is arbitrarily or discriminatorily underrepresented on the jury venire.

White v. Georgia, 414 U.S. 886, 890 (1973) (Brennan, J., joined by Douglas and Marshall, JJ., dissenting from dismissal of appeal).

161. See text at notes $169-71$ infra.

162. Unfortunately, some courts have indicated at least partial agreement with such an interpretation. See cases cited in note 159 supra.

163. 407 U.S. 493, 503-04 (1972) (opinion of Marshall, J., joined by Douglas and Stewart, JJ.), approvingly noted in Taylor v. Louisiana, 419 U.S. 522, $532 \mathrm{n} .12$ (1975).

164. Taylor v. Louisiana, 419 U.S. 522, 526 (1975).

165. Peters v. Kiff, 407 U.S. 493 (1972). 
ond criterion should not be applied conjunctively, as Guzman suggests, but disjunctively. Either a finding that members of an age group share common ideas or experiences which cannot be represented adequately in their absence or that possible partiality or bias against a defendant if members of his age group are excluded warrant a designation of cognizability if the first criterion is also satisfied.

\section{Establishing the Cognizability of Young Adults ${ }^{166}$}

As Part II has shown, problems of group definition and failure of proof have been the two main obstacles to the cognizability of young adults. The following discussion will demonstrate that these obstacles can be surmounted. Although courts may be correct in refusing to recognize age groups spanning only a few years, their refusal to recognize larger age groups is unreasonable. Moreover, the courts' unwillingness to assume that young adults have attitudes, ideas, and experiences different from those of their elders and that young criminal defendants may be prejudiced by the absence of their peers on juries can and should be overcome with proof of these facts.

\section{A. Defining Young Adults}

Administratively convenient definitions of "young adults" can be written. It is easy to tell whether a person is a member of a group aged eighteen to thirty, for example, because age itself both defines and limits the group. Although the group's composition changes with the passage of time, the change is slight from year to year, and that gradual change is not significantly greater than the change in racial or gender groups through disqualification from service, use of exemptions, or movement into or out of a jurisdiction.

The boundaries of an age group are indeed somewhat arbitrary and often could be altered slightly without noticeably changing the group character. Society draws many lines by age which are some-

166. The discussion and data presented in the remainder of the Article strongly support the conclusion that older age groups as well as younger age groups are cognizable. Federal law and the laws of most states do not impose upper age limits on jury service, and persons over age 65 apparently are substantially underrepresented on the jury rolls in most jurisdictions. See J. VAN DYKE, supra note 4, at 35-39, 258-70 app. A, 332-47 app. H. The complete absence of challenges to underrepresentation of the elderly probably stems from the fact that older jurors are more conservative and tend to have a stronger law and order orientation than younger jurors. Since criminal defendants bring most challenges to selection procedures, challenges to the underrepresentation of the elderly probably seem counter-productive. Underrepresentation of young adults is even greater than underrepresentation of the elderly in most jurisdictions, J. VAN DYKE, supra note 4, at 332 app. H, and the issue is approached here from the perspective of the young. 
what arbitrary, however. It surely does not follow that we would be better off drawing no line at all. ${ }^{167}$ Here, if it is clearly shown that young adults generally have different attitudes from their elders, and if the location of the boundary between them can be roughly indicated, then it hardly seems sensible to deny the group's cognizability simply because any boundary drawn in that range will be as rational as any other. Such reasoning apparently persuaded the court in Butera. While conceding that young adults were an "ill-defined" group, the court stated: "We cannot allow the requirement of a 'distinct' group to be applied so stringently with regard to age grouping that possible discrimination against a large class of persons-in our case, those between twenty-one and thirty-four-will be insulated from attack." 168

At the root of judicial concern about group definition might be the fear that if young adults are recognized as cognizable, age groups with short time spans must also be recognized. ${ }^{169}$ But that conclusion does not follow from the premise. People perceive themselves, and are perceived by others, as members of broad age categories-as young adults, middle-aged, or elderly-not, for example, as twentyone to twenty-three year olds. 170 An age group of only two or three years span will differ little in attitude from a similarly narrow group of the same span which is just older than the first, or just younger. The kind of proof of attitude examined in the next section will simply not be available for groups spanning less than approximately ten years. Consequently, the fear that recognizing young adults will open the floodgates to challenges by narrow age groups is unwarranted. ${ }^{171}$

167. In Massachusetts Bd. of Retirement v. Murgia, 427 U.S. 307 (1976), the Supreme Court upheld a statute requiring that state police retire at age 50, despite the age limit's inevitable arbitrariness. The Court stated, "[T]he drawing of lines that create distinctions is . . . unavoidable. ... Perfection in making the necessary classifications is neither possible nor necessary." 427 U.S. at 314 . Since physical fitness generally declines with age, the Court found that the Massachusetts requirement was rationally related to the legitimate state objective of assuring the physical preparedness of its police officers. 427 U.S. at 314-15.

If courts endorse, as they must and do, somewhat arbitrary age limitations which impose substantial hardships on persons in certain age groups, they should also be willing to endorse a somewhat arbitrary definition of young adults for jury selection purposes which imposes hardships on no one.

168. 420 F.2d 564, 570 (1st Cir. 1970).

169. See cases cited in notes 153-54 supra.

170. See Part III. B infra.

171. Apparently similar to the problem of defining the contours of a cognizable age group is the problem of determining the minimum age requirement for jury service. These issues are distinct, however. As note 167 supra suggests, the first issue is whether the judiciary should employ an inevitably arbitrary measure to protect constitutional rights; the second is whether the state constitutionally may employ such a measure to protect its interest in choosing mature, responsible jurors. 


\section{B. Age as a Determinant of Attitude}

It has become a social scientists' truism that the young share common and distinct attitudes. The social scientist's evidence speaks to all the traditional criteria of cognizability. That evidence supplements the above argument that "the young" are easily defined, and the presence of common attitudes suggests that the young are "cohesive." Finally, the evidence provides a basis for the inference that the attitudes of the young differ sufficiently from those of the rest of the population that excluding the young from juries would adversely affect the quality of deliberation.

Age crucially influences people's thoughts and acts:

Age, in Mannheim's insightful formulation, "locates" individuals in the social structure. There is much evidence that, for example, a person's activities, his attitudes toward life, his relationships to his family or to his work-as well as his biological capacities and his physical fitness - are all conditioned by his position in the age structure of the particular society in which he lives. ${ }^{172}$

Age differences in society are not random; they are patterned and systematic. Indeed, "age operates as a basis of social stratification much like class" 173 and divides our society into three broad, postchildhood segments: the young, middle-aged and aged. ${ }^{174}$ In addition,

age orders both people and roles. Not only is the population ranked according to age, but social roles, with their differing rewards, are defined in terms of age and age-related criteria. The result is the forma-

Aside from this line-drawing problem, minimum age requirements might appear to undermine the thesis that the young are cognizable. If the very young can be excluded from jury service entirely, why may not the state employ selection procedures which merely underrepresent those slightly older? Is it not a paradox that a state which gives 18- to 21-year-olds the legal right to serve might be forbidden from systematically excluding them, even though another state might be permitted to deny the same group the right to serve?

This paradox can be explained by an analogy to another important citizenship right, the right to vote. Although a state might constitutionally deny the vote to 17-year-olds, it could not grant them the vote conditionally by, for instance, imposing a poll tax. Similarly, once the state has announced that a class of persons deserves to serve on juries, it cannot allow capricious devices that effectively cancel their right to serve. Government integrity demands that citizenship rights be granted fully or not at all.

In large part, the paradox is only of theoretical interest. Since the minimum age for jury service probably could not be constitutionally raised much above the age of 21 , and since the age group 21-30 is sufficiently large and distinct to be cognizable, the underrepresentation of young people can still be successfully challenged.

172. 3 M. RILEY, M. Johnson \& A. Foner, AGING AND Society 398 (1972) phereinafter cited as AGING AND Society 1972]. See also Foner, Age in Society: Structure and Change, 19 AM. BeHAVIORAL SCIENTIST 144, 148 (1975).

173. Foner, supra note 172, at 145 ; see 1 M. RILEY \& A. FonER, AGING AND SocietY (1968) [hereinafter cited as AGING AND SOCIETY 1968].

174. AGING AND Society 1968, supra note 173, at 2; AGING AND Societr 1972, supra note 172 , at 420 . 
tion of age strata distinguished from one another because their members differ in age or life stage and in access to roles which are unequally rewarded by wealth, prestige, or power. ${ }^{175}$

Age stratification has become more important in our society. In the nineteenth century,

the boundaries between age strata were not so clearly defined, and there was a good deal more age heterogeneity in social life than there is today. But in the modern period, with the great complexity of social organizations and the high degree of bureaucratization, age has increasingly become an important criterion for social differentiation and inequality. ${ }^{176}$

Today the differences associated with age are ubiquitous. Age groups differ in "labor force participation, consumer behavior, leisure-time activities, marital status, religious behavior, education, nativity, fertility, child-rearing practices, political attitudes-to name only a few."177 Moreover, "[o]lder people differ sharply from younger people in many of their opinions, feelings, and dispositions toward such central aspects of life as health, personal problems, or death."178 The old also tend to be more politically conservative, more resistant to change, and less tolerant of political and social nonconformists than the young. 179 "It comes as no surprise, then, that each age strata has its own distinctive subculture."180

An examination of the causes of age-group differences demonstrates how and why those groups form recognizable social categories with fairly well-defined boundaries. First, at any given period members of an age stratum belong to the same birth cohort, "[e]ach cohort [having] unique characteristics because of the particular historical events it has undergone, [and] the particular knowledge and attitudes it has acquired in childhood. . .."181 Cohesion in each cohort is fostered by a "homogeneity in values and beliefs (about what is good, beautiful or true) among individuals who were educated at

175. Foner, supra note 172, at 147 (references omitted); see AGING AND SOCIETY 1968, supra note 173 , at $410-12$.

176. Affidavit of Dr. Anne Foner at 15, Johnson v. Durante, No. 73C 1159-EN (E.D. N.Y., filed Aug. 3, 1973) (submitted as direct testimony). In that case, the systematic exclusion of those aged 18-30 from grand jury service in Queens County, New York, was challenged. See also Neugarten \& Hagestad, Age and the Life Course, in HANDBooK of AGING AND THE Social SCIENCES 35, 45, 52 (R. Binstock \& E. Shanas eds. 1976).

177. AGING AND SocIETY 1972, supra note 172, at 420.

178. AgING AND Society 1968, supra note 173, at 315. See also AGING AND SocietY 1972 , supra note 172 , at 431 .

179. AGING AND SocietY 1968, supra note 173, at 5, 473. See AGING AND SocieTY 1972, supra note 172 , at $115-19,132-34$.

180. AGING AND Society 1972, supra note 172, at 420 (emphasis original).

181. AGING AND Society 1968, supra note 173, at 3. See also Foner, supra note 172, at 151; AGING AND SocietY 1972, supra note 172, at 4, 418-19, 432-33. 
the same point in history." 182 Conversely, differences in life stage and experience may engender hostility and conflict between age strata. ${ }^{183}$

A second factor making for distinct age groups is the commonalities of life stage shared by group members.

Like persons within a class, individuals of similar age at any one period have common opportunities to fill valued roles. They share the joys and pains of current life tasks. Because they are at the same stage of their life course, they resemble one another in biological development and in the role sequences and role transitions they have experienced. ${ }^{184}$

The extensive age segregation in the United States further promotes solidarity between those of the same age and insulates members of one group from members of another. Age segregation is common in education, employment, and residency. Face-to-face contact within age strata reinforces similar ideas and attitudes, while often allowing members of one stratum to remain unaware of or unsympathetic to the ideas of other strata. ${ }^{185}$

The sociological findings on the importance of age in determining attitudes go to the essence of cognizability. The unique perspectives and shared experiences of young adults simply cannot be represented adequately by their elders. Because age groups differ in varied and subtle ways, underrepresentation of the young on juries inevitably diminishes the interplay of ideas and viewpoints during deliberations. As when women are absent, "a flavor, a distinct quality is lost"186 if young adults are seriously underrepresented on jury rolls.

\section{AtTitudes and Opinions of Particular Importance in JURY DELIBERATIONS}

The evidence presented above permits the inference that the young meet the third criterion of cognizability-that their attitudes are so different from those of the rest of the population that the quality of a jury's deliberation would be significantly affected by the ab151.

182. AgING AND Society 1968, supra note 173, at 5. See also Foner, supra note 172, at

183. Waring \& Riley, Age and Aging, in Contemporary Social Problems 363 (4th ed. R. Merton \& R. Nisbet 1976). See also Foner, supra note 172, at 153-54; AGING AND SocietY 1972, supra note 172 , at $145,442-48$.

184. Foner, supra note 172 , at $150-51$. 79.

185. See generally Foner, supra note 172, at 151; Waring \& Riley, supra note 183, at 377-

186. Ballard v. United States, 329 U.S. 187, 193-94 (1946). 
sence of the young. However, since the evidence is inferential only, this Article presents the results of a survey which speaks directly to the question whether excluding the young would affect the nature of a jury's discussions and decisions. The results of this survey are especially significant in that such specific proof has apparently never been presented in discussions of cognizability.

The survey was conducted in Queens County, New York. ${ }^{187}$ It reveals consistent and significant differences in attitudes among persons in different age groups on matters crucial to jury deliberations. The greatest disparities in attitudes are those between the youngest (18-30) and oldest (61-75). The data also show that the correlations between attitudes and age are much greater than the correlations between attitudes and race, sex, occupation, or income. Since racial groups, women, and on occasion, occupational and income groups, have been held cognizable, young adults are cognizable a fortiori.

\section{A. Methodology 188}

The survey was specifically designed to elicit attitudes concerning the workings of the criminal justice system and service on petit and grand juries. The questionnaire contained twenty-one opinion statements $^{189}$ and requested demographic information. Systematically

187. The results of the survey were submitted at trial in Johnson v. Durante, No. $73 \mathrm{C}$ 1159-EN (E.D.N.Y., filed Aug. 3, 1973), in support of the plaintiffs' challenge to the exclusion of the young from grand jury service in that county.

For a comparison of the demographic characteristics of Queens County and the United States as a whole, see Appendix D infra.

188. Appendix A infra describes in greater detail the methodology of the survey.

189. A copy of the full questionnaire may be found in Appendix A (Exhibit 1). The 21 opinion statements (numbered as on the questionnaire) are as follows:

1. It is better to let some guilty people go free rather than risk sending innocent people to jail.

2. Police should not hesitate to use force to maintain order.

3. Capital punishment is more effective than a life sentence in keeping people from committing murder.

4. The courts allow young people to get away with too much too easily.

5. Police should be allowed to arrest and question suspicious looking persons to determine whether they have been up to something illegal.

6 . A witness who takes the fifth amendment is probably hiding his or her guilt of a crime.

7. Police will often lie to cover up for one another.

8. In tough situations older people almost always make wiser decisions than younger people.

9. Young people have less respect for law than older people.

10. A person accused of several different crimes is probably guilty of at least one of them.

11. The police don't make arrests unless they have good reason to believe that a crime has been committed.

12. Too often, the government brings people to trial who are not really guilty.

13. Obedience to authority is the most important virtue children should leam.

14. In criminal cases the judge instructs the jury that the defendant must be considered innocent unless proven guilty. However, many people think that a defendant has the 
chosen samples of those on the petit and grand jury rolls and of members of the general public were contacted by telephone, and 579 interviews were completed. For all but three statements, respondents were asked to tell the interviewer whether they agreed strongly, agreed somewhat, disagreed somewhat, or disagreed strongly with the statement read to them. For convenience, the "agree strongly" and "agree somewhat" responses are combined in the presentation below. ${ }^{190}$ Three statistical procedures were used to analyze the survey data: tables of percentages, Pearson product-moment correlation coefficients, and standardized multiple regression coefficients. Each is explained in context.

\section{B. The Findings}

\section{The Relationship Between Age and Attitudes}

The survey results demonstrate significant correlations between age and attitudes among the groups sampled. ${ }^{191}$ Since space constraints prohibit a discussion of all twenty-one statements, only six statements are discussed. However, the responses are representative of the responses by age for all twenty-one statements. ${ }^{192}$

Statement 6 was: " $A$ witness who takes the fifth amendment is prob-

responsibility to prove his or her innocence. If you were a member of a jury in a criminal case, would you follow the judge's instructions or would you want the defendant to prove innocence?

15. If you were a member of a jury in a criminal case and truly believed that the person on trial was guilty but the evidence didn't prove it, would you vote to find the person guilty or not guilty?

19. If a District Attorney strongly recommends an indictment grand jurors should go along with the recommendation.

20. Grand jurors rarely need to exercise their right to ask questions of witnesses because

they can rely on the District Attorney to ask all necessary questions.

21. During deliberations, if one grand juror disagrees with the rest of the jurors that person should change his or her vote to go along with the majority.

22. Since the District Attorney is more familiar with the evidence, the grand jury should always follow his recommendations.

23. District Attorneys sometimes conceal evidence from a grand jury in order to get an indictment.

24. Do you think Society would be better served if the grand jury represented all segments of the community or if it was composed of older, more experienced people?

Questions 16 through 18 are omitted here and in the analysis of results because they were designed to probe the respondent's understanding of a grand jury, not to elicit an opinion.

190. The percentage disagreeing with the statement in each group may be determined by subtracting the percentage listed in the tables from $100 \%$.

191. Of the three groups sampled, $10 \%$ of the general public had served on a petit jury, $58 \%$ of those from the petit jury pool had served on a petit jury, and $60 \%$ of those from the grand jury pool had served on a grand jury. Data runs were conducted controlling for the fact of service as to all 21 opinion statements. The results showed virtually no differences in opinion between those who had served and those who had not served on juries. Thus, it can be inferred that jury service does little to modify one's attitudes, at least as to the issues probed in this survey.

192. Appendix $\mathrm{C}$ infra gives a complete set of percentage tabulations for all the demographic variables-age, race, sex, occupation, and income. 
ably hiding his or her guilt of a crime." Table 1 shows the percentage agreeing with this statement by age and sample. ${ }^{193}$

TABLE 1

Percentage Agreeing with Statement 6 by Age

Statement 6: "A witness who takes the fifth amendment is probably hiding his or her guilt of a crime."

\begin{tabular}{|c|c|c|c|c|c|c|}
\hline \multirow[b]{2}{*}{ Sample } & \multicolumn{4}{|c|}{ Age } & \multirow[b]{2}{*}{ \% Diff. 194} & \multirow{2}{*}{$\begin{array}{c}\text { Level of } \\
\text { Significance }\end{array}$} \\
\hline & $18-30$ & $31-45$ & $46-60$ & $61-75$ & & \\
\hline General Public & 39 & 59 & 64 & 74 & +35 & .01 \\
\hline Petit Jurors & 33 & 50 & 52 & 80 & +47 & .001 \\
\hline Grand Jurors & 12 & 13 & 38 & 84 & +72 & .001 \\
\hline
\end{tabular}

In all three samples, younger people agreed with Statement 6 much less frequently than older people. Moreover, there is a clear trend in each sample of increasing agreement from the youngest to the oldest age groups. And in all three samples, the difference in attitude is greatest between the youngest and the oldest groups. In the grand juror sample, the difference is an unusually large seventytwo percent. The responses to Statement 6 suggest that if young adults are absent from jury rolls, the right to invoke the fifth amendment may not be fully recognized.

The ninth statement read to those surveyed was: "Young people have less respect for law than older people." Table 2 shows the percentages agreeing with this statement in each age group in the three samples.

The data in Table 2 show the same general patterns as the data in Table 1. Older people agreed with the statement much more frequently than younger people, and there is a clear trend in each sample of increasing agreement from the youngest to the oldest groups. Further, in the general public and petit juror samples, the difference in attitude is greatest between the youngest and the oldest.

193. On the average for all statements, less than $5 \%$ of those surveyed were unable or unwilling to give an opinion. This low rate indicates that the statements were meaningful and clear to those surveyed.

194. The percentage differences listed are the differences between the left-most and rightmost categories of the social characteristic. The level of significance is .01 for the general public sample, using the chi-square $\left(x^{2}\right)$ test. This indicates that there is only one chance in one hundred that the observed relationship ( $+35 \%$ difference) could have occurred in the sample solely as a result of sampling error (i.e., without the relationship existing in the population from which the sample was drawn). Note that lower levels of significance are better, iee, indicate lower probabilities of sampling error. Stronger relationships (higher percent differences) and larger sample sizes each contribute to statistical significance and to greater sample reliability. For a discussion of chi-square and other tests of statistical significance, see W. WyatT \& C. BRIDGES, Statistics For THE BeHaVIORAL SCIENCES (1967). 
TABLE 2 .

Percentage Agreeing with Statement 9 by Age

Statement 9: "Young people have less respect for law than older people."

\begin{tabular}{|c|c|c|c|c|c|c|}
\hline \multirow[b]{2}{*}{ Sample } & \multicolumn{4}{|c|}{ Age } & \multirow[b]{2}{*}{ \% Diff. } & \multirow[b]{2}{*}{$\begin{array}{c}\text { Level-of } \\
\text { Significance }\end{array}$} \\
\hline & $18-30$ & $31-45$ & $46-60$ & $61-75$ & & \\
\hline General Public & 48 & 62 & 63 & 90 & +42 & .01 \\
\hline Petit Jurors & 42 & 63 & 80 & 80 & +38 & .001 \\
\hline Grand Jurors & 38 & 37 & 55 & 86 & +48 & .01 \\
\hline
\end{tabular}

In addition to Statement 9, Statements 4,8 , and 24 raise issues dealing explicitly with age. The responses are only slightly less striking than those recorded for Statement 9.195 These results suggest an underlying pattern of hostility toward the young among older people, some of whom might presume that young people accused of crime are ipso facto guilty. Thus, a jury on which young adults are underrepresented might be less likely to accord a young defendant the full presumption of innocence. ${ }^{196}$ Because most persons accused of crime are under thirty, 197 the nearly universal underrepresentation of the youngest age group on jury rolls poses a danger of age bias in most criminal cases.

The tenth statement read: " $A$ person accused of several different crimes is probably guilty of at least one of them." Table 3 shows the percentages of people who agreed with this statement in each age group in the three samples.

TABLE 3

Percentage Agreeing with Statement 10 by Age

Statement 10: "A person accused of several different crimes is probably guilty of at least one of them."

\begin{tabular}{|c|c|c|c|c|c|c|}
\hline \multirow[b]{2}{*}{ Sample } & \multicolumn{4}{|c|}{ Age } & \multirow[b]{2}{*}{$\%$ Diff. } & \multirow[b]{2}{*}{$\begin{array}{c}\text { Level of } \\
\text { Significance }\end{array}$} \\
\hline & $18-30$ & $31-45$ & $46-60$ & $61-75$ & & \\
\hline General Public & 53 & 44 & 63 & 83 & +30 & .01 \\
\hline Petit Jurors & 38 & 54 & 60 & 77 & +39 & .05 \\
\hline Grand Jurors & 41 & 28 & 37 & 66 & +25 & .05 \\
\hline
\end{tabular}

195. See Appendix C infra.

196. Statement 14, printed in note 189 supra, explicitly probes attitudes toward the presumption of innocence. Although the responses are less striking than the responses to Statements $4,8,9$, and 24 , see Appendix $C$ infra, they are consistent with the conclusion that the underrepresentation of young adults might result in juries which undervalue that presumption.

197. In 1974, for example, $27.2 \%$ of all the persons arrested in the United States were under age 18 , and $41.6 \%$ were between the ages of 18 and 29 . Persons over age 30 , by contrast, constituted only $31 \%$ of those arrested. M. Hindelang, M. Gottfredson, C. DUNN \& N. Parisi, Sourcebook of Criminal Justice Statistics-1976, at 528-29 table 4.4 (1977) [hereinafter cited as Sourcebook of Criminal Justice Statistics]. 
In general, older people agreed with this statement much more often than younger people. In this instance, however, the results do not show a consistent trend of increasing agreement from the youngest to the oldest groups in the general public and grand juror samples. As in the previous examples, however, the differences in attitude between the youngest and the oldest age groups are great. In the sample of the general public, thirty percent more of those in the sixty-one to seventy-five age group agreed with the statement than those in the eighteen to thirty age group, and the differences between these age groups in the petit juror and grand juror samples were thirty-nine and twenty-five percentage points respectively.

The first statement was: "It is better to let some guilty people go free rather than risk sending innocent people to jail." Table 4 shows the percentage in each group in each sample who disagreed ${ }^{198}$ with this statement.

TABLE 4

Percentage Disagreeing with Statement 1 by Age

Statement 1: "It is better to let some guilty people go free rather than risk sending innocent people to jail."

\begin{tabular}{|c|c|c|c|c|c|c|}
\hline \multirow[b]{2}{*}{ Sample } & \multicolumn{4}{|c|}{ Age } & \multirow[b]{2}{*}{ \% Diff. } & \multirow[b]{2}{*}{$\begin{array}{c}\text { Level of } \\
\text { Significance }\end{array}$} \\
\hline & $18-30$ & $31-45$ & $46-60$ & $61-75$ & & \\
\hline General Public & 48 & 38 & 48 & 64 & +16 & .20 \\
\hline Petit Jurors & 49 & 55 & 45 & 62 & +13 & Not Sig. \\
\hline Grand Jurors & 44 & 36 & 36 & 42 & -2 & Not Sig. \\
\hline
\end{tabular}

Statement 1 is one of a few of the twenty-one opinion statements for which there is not a clear and striking relationship between age and attitude. ${ }^{199}$ In the general public and petit juror samples, older people were somewhat more likely than younger people to disagree and, once again, the greatest differences were between the youngest (or next youngest) and oldest age groups. However, there is not a consistent trend of increasing disagreement from the youngest to the

198. Statement 1 was one of four statements which were phrased in a "liberal" rather than a "conservative" manner. The other "liberal" statements are 7, 12, and 23. See note 189 supra. Generally, the responses to these items tended to be the opposite of the responses to the statements phrased conservatively; that is, younger people more often agreed and older people more often disagreed with these statements. Percentages for those who disagreed with the statements are listed to make the complete set of percentages tabulated in Appendix C more readable.

199. Other statements for which the relationship between age and attitude is rather weak are Statements 7 and 12, printed in note 189 supra. A stronger but still less than striking relationship is exhibited for Statements 14,15, 19, and 23, printed in note 189 supra. 
oldest groups. Moreover, in the grand juror sample, the maximum difference between any two age groups was only eight percent.

Questionnaire statements 19-24 were designed to elicit attitudes toward grand jury matters directly. For example, Statement 21 was: "During deliberations, if one grand juror disagrees with the rest of the jurors, that person should change his or her vote to go along with the majority." Table 5 shows the percentages who agreed with the statement in each age group and sample.

TABLE 5

Percentage Agreeing with Statement 21 by Age

Statement 21: "During deliberations, if one grand juror disagrees with the rest of the jurors, that person should change his or her vote to go along with the majority."

\begin{tabular}{|c|c|c|c|c|c|c|}
\hline \multirow[b]{2}{*}{ Sample } & \multicolumn{4}{|c|}{ Age } & \multirow[b]{2}{*}{$\%$ Diff. } & \multirow{2}{*}{$\begin{array}{c}\text { Level of } \\
\text { Significance }\end{array}$} \\
\hline & $18-30$ & $31-45$ & $46-60$ & $61-75$ & & \\
\hline General Public & 7 & 7 & 8 & 33 & +26 & .01 \\
\hline Petit Jurors & 2 & 9 & 13 & 18 & +16 & .15 \\
\hline Grand Jurors & 0 & 0 & 3 & 25 & +25 & .01 \\
\hline
\end{tabular}

A clear relationship between age and attitude is exhibited by the responses in all three samples-i.e., older people agreed with the statement more often than younger people. Furthermore, there is a clear trend of increasing agreement from the youngest to the oldest groups in all samples. The responses of those in the oldest age group were markedly different from the responses of those in the other age groups.

The responses to Statement 22 were very similar to the responses to Statement 21. Statement 22 was: "Since the District Attorney is more familiar with the evidence, the grand jury should always follow his recommendations." The percentages agreeing by age and sample are listed in Table 6.

\section{TABLE 6}

\section{Percentage Agreeing with Statement 22 by Age}

Statement 22: "Since the District Attorney is more familiar with the evidence, the grand jury should always follow his recommendations."

Age

Sample

General Public

Petit Jurors

Grand Jurors

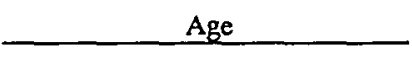

$18-30 \quad 31-45 \quad 46-60 \quad 61-75 \quad \%$ Diff. Significance

Once again, older people agreed with the statement much more 
often than younger people. The pattern of increasing agreement by age is repeated for the most part. Finally, the differences in attitude in each sample between the youngest and oldest groups were large. In the general public sample, the difference in response between these groups was a substantial fifty-three percentage points.

The responses to Statements 21 and 22, as well as the responses to the other statements concerning grand jury service, ${ }^{200}$ suggest that people between the ages of eighteen and thirty are more likely to be inclined to exercise independent judgment than are older people, especially those between the ages of sixty-one and seventy-five. Grand juries on which young adults are substantially underrepresented thus may be much more inclined to act as a rubber stamp for the prosecutor than grand juries on which the young are properly represented.

In sum, these data documenting the relationship between age and attitude on matters of importance in jury deliberations support the conclusion that young adults are cognizable. The data show clear and consistent differences of opinion by age on such matters as the inference of guilt from silence, the presumption of innocence, the predisposition of the young to break the law, the performance and prerogatives of the police, ${ }^{201}$ and the role of the grand juror vis-à-vis the district attorney. These results go to the heart of cognizability. They demonstrate that the young have cohesive, distinct attitudes on issues directly relevant to a jury's deliberations. Furthermore, they demonstrate that permitting underrepresentation of the young on juries would be especially unfortunate, since the attitudes of the young tend to be more congruent than those of the old with the values which inform our legal system. Thus underrepresentation of the young increases the risk of several kinds of jury bias, especially bias against young criminal defendants. ${ }^{202}$

200. See Appendix C infra, Statements 19-24.

201. In addition to Statement 10 , discussed in text following note 197 supra, see Statements $2,5,7$, and 11 , printed in note 189 supra.

202. Other data are consistent with those presented above. The responses to the questions concerning criminal justice issues presented in SourCEBOOK OF CRIMINal JUSTICE STATISTICS, supra note 197, show a significant relationship between age and attitude. Perceptions of personal safety differ according to age. Fifty-two percent of those aged 20-24 said they felt "very" safe about being out alone in their neighborhood during the day, while only $41 \%$ of those aged 50-64 and only $31 \%$ of those above age 65 said they felt "very" safe. Id. at 304 table 2.8. Correspondingly, younger people are less likely than older people to think law enforcement agencies should be tougher than they are now in dealing with crime and lawlessness. Only $66 \%$ of the persons aged $18-20$ favored tougher enforcement, while $85 \%$ of those aged 50 and over held that opinion. Id. at 316 table 2.29. Older people were more likely to favor the death penalty and less likely to favor legalization of marijuana than younger people. Id. at 327 table 2.61, 342 table 2.91 .

A similar relationship between age and attitude concerning criminal justice issues was found in a Detroit Free Press survey of 500 jurors in 1970. Oppedahl, The Generational Gap in 
2. Comparison of the Correlations Between Attitudes and Age with the Correlations Between Attitudes and Race, Sex, Occupation, and Income

The survey results provide important additional support for the cognizability of the young, since they reveal that the correlations between attitudes and age are stronger than the correlations between attitudes and race, sex, occupation, or income.

a. Correlation analysis. The percentage table method of analysis used in the discussion of age and attitudes is too unwieldy to use in analyzing all the demographic variables. Instead, Pearson product-moment correlation coefficients are used. ${ }^{203}$ Five tables of percentages and a corresponding table of correlations are presented for one opinion statement so that the reader may understand fully the manner in which correlation coefficients summarize the data.

The Pearson product-moment correlation coefficient, symbolized by $\mathrm{r}$, summarizes the relationship between two variables (e.g., age and attitude) in a single number. This coefficient ranges from -1.0 to +1.0 . The sign of the coefficient indicates the nature of the relationship between the social characteristic and the opinion statement. In the context of this survey, positive correlations mean that older people, nonwhites, females, persons with higher occupational status, and persons with higher incomes more often agree with the statement. If the sign is negative, younger people, whites, males, persons with lower occupational status, and persons with lower incomes more often agree with the statement. The closer $\mathrm{r}$ is to 1.0 , whether positive or negative, the stronger the relationship between the demographic variable and the attitude. A large $r$ thus corresponds to a large difference in percentages. ${ }^{204}$ If the value of $r$ is zero or close to zero, there is little or no consistent relationship between the demographic variable and the attitude, corresponding to little or no difference in the percentages.

Court, Detroit Free Press, July 26, 1971, \& A, at 1, col. 2. The results of the survey are presented in part in J. VAN DYKe, supra note 4, at 37-38. See also Ginger \& Powers, Mississippi Juror Age Requirement-Unfair to the Defendant, Unfair to the Young, and Unfair to the Public-1s It Constitutional?, 47 Miss. L.J. 1 (1976).

203. For an explanation of this statistical technique, see H. BLALOCK, Social STATISTICS 285-99 (1960).

204. The value of $r$ does not correspond only to the percentage difference between the extreme categories of the demographic variable (here, young adults vs. the aged), it accounts for the percentage differences between all categories, including intermediate ones (here, those aged 31-45 and 46-60). One mark of the sophistication of correlation analysis is this ability to explain a statistical trend along an entire spectrum of categories. For an illustration, see text at note 206 infra. 
The percentages of people in each of the three samples who agreed with Statement 6 (" $A$ witness who takes the fifth amendment is probably hiding his or her guilt of a crime.") by age, race, sex, occupation and income are shown in Table 7. The correlation coefficients summarizing these data are shown in part $F$ of Table 7.

TABLE 7

Percentage Agreeing with Statement 6 by Age, Race, Sex, OCCUPATION AND INCOME, AND CORRESPONDING CORRELATION COEFFICIENTS

Statement 6: "A witness who takes the fifth amendment is probably hiding his or her guilt of a crime."

\begin{tabular}{|c|c|c|c|c|c|c|}
\hline \multirow[b]{2}{*}{ Sample } & \multicolumn{4}{|c|}{ A. Age } & \multirow[b]{2}{*}{$\%$ Diff. } & \multirow[b]{2}{*}{$\begin{array}{c}\text { Level of } \\
\text { Signigicance }\end{array}$} \\
\hline & $18-30$ & $31-45$ & $46-60$ & $61-75$ & & \\
\hline General Public & 39 & 59 & 64 & 74 & +35 & .01 \\
\hline Petit Jurors & 33 & 50 & 52 & 80 & +47 & .001 \\
\hline Grand Jurors & 12 & 13 & 38 & 84 & +72 & .001 \\
\hline
\end{tabular}

\begin{tabular}{|c|c|c|c|c|c|c|c|c|c|}
\hline \multirow[b]{2}{*}{ Sample } & & & \multicolumn{4}{|c|}{ B. Race } & & \multirow{2}{*}{$\begin{array}{c}\text { Level of } \\
\text { Significance }\end{array}$} \\
\hline & & & \multicolumn{2}{|l|}{ White } & \multicolumn{2}{|c|}{ Nonwhite } & \multicolumn{2}{|r|}{$\%$ Diff. } & \\
\hline $\begin{array}{l}\text { General Public } \\
\text { Petit Jurors } \\
\text { Grand Jurors }\end{array}$ & & & $\begin{array}{l}58 \\
56 \\
55\end{array}$ & & & $\begin{array}{l}8 \\
4 \\
6\end{array}$ & & $\begin{array}{r}0 \\
-2 \\
+11 \\
\end{array}$ & $\begin{array}{c}\text { Not Sig. } \\
\text { Not Sig. } \\
.10\end{array}$ \\
\hline \multirow{2}{*}{\multicolumn{3}{|c|}{ Sample }} & \multicolumn{4}{|c|}{ C. Sex } & \multirow{2}{*}{\multicolumn{2}{|c|}{$\%$ Diff. }} & \multirow[b]{2}{*}{$\begin{array}{c}\text { Level of } \\
\text { Significance }\end{array}$} \\
\hline & & & \multicolumn{2}{|l|}{ Male } & \multicolumn{2}{|c|}{ Female } & & & \\
\hline \multicolumn{2}{|l|}{$\begin{array}{l}\text { General Public } \\
\text { Petit Jurors } \\
\text { Grand Jurors }\end{array}$} & & $\begin{array}{l}54 \\
57 \\
54\end{array}$ & & \multicolumn{2}{|c|}{$\begin{array}{l}62 \\
58 \\
63\end{array}$} & \multicolumn{2}{|r|}{$\begin{array}{l}+8 \\
+1 \\
+9\end{array}$} & $\begin{array}{l}\text { Not Sig. } \\
\text { Not Sig. } \\
\text { Not Sig. }\end{array}$ \\
\hline \multirow[b]{2}{*}{ Sample } & \multicolumn{6}{|c|}{ D. Occupation } & & \\
\hline & 离管 & 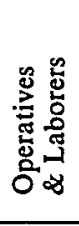 & 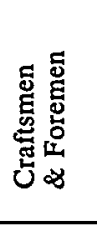 & 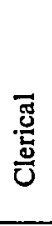 & $\frac{\mathscr{\omega}}{\bar{n}}$ & 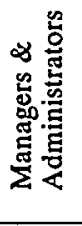 & 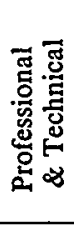 & \% Diff. & $\begin{array}{c}\text { Level of } \\
\text { Significance } \\
\end{array}$ \\
\hline $\begin{array}{l}\text { General Public } \\
\text { Petit Jurors } \\
\text { Grand Jurors }\end{array}$ & $\begin{array}{l}58 \\
78 \\
74\end{array}$ & $\begin{array}{r}64 \\
64 \\
100\end{array}$ & $\begin{array}{l}75 \\
54 \\
70\end{array}$ & $\begin{array}{l}48 \\
63 \\
69\end{array}$ & $\begin{array}{l}56 \\
65 \\
74\end{array}$ & $\begin{array}{l}82 \\
39 \\
52\end{array}$ & $\begin{array}{l}57 \\
48 \\
34\end{array}$ & $\begin{array}{l}-1 \\
-30 \\
-40\end{array}$ & $\begin{array}{c}.20 \\
\text { Not Sig. } \\
.05\end{array}$ \\
\hline
\end{tabular}




\begin{tabular}{|c|c|c|c|c|c|c|c|c|}
\hline \multirow[b]{2}{*}{ Sample } & \multicolumn{6}{|c|}{ E. Income } & \multirow{2}{*}{\multicolumn{2}{|c|}{$\begin{array}{cc}\text { Level of } \\
\text { fr. } & \text { Significance }\end{array}$}} \\
\hline & $\begin{array}{l}\text { Under } \\
\$ 5000 \\
\end{array}$ & $\begin{array}{l}\$ 5000- \\
\$ 10000 \\
\end{array}$ & $\begin{array}{l}\$ 10000- \\
\$ 15000 \\
\end{array}$ & $\begin{array}{r}\$ 15000- \\
\$ 20000 \\
\end{array}$ & $\begin{array}{l}\$ 20000- \\
\$ 25000 \\
\end{array}$ & $\begin{array}{c}\text { Over } \\
\$ 25000 \\
\end{array}$ & & \\
\hline General Public & 59 & 72 & 40 & 75 & 66 & 41 & -18 & .01 \\
\hline Petit Jurors & 82 & 76 & 58 & 39 & 52 & 49 & -33 & .05 \\
\hline Grand Jurors & 86 & 79 & 71 & 34 & 49 & 27 & -59 & .02 \\
\hline
\end{tabular}

F. Correlation Coefficients 205

\begin{tabular}{|c|c|c|c|c|c|}
\hline Sample & Age & $\begin{array}{c}\text { Nonwhite } \\
\text { Race }\end{array}$ & $\begin{array}{c}\text { Female } \\
\text { Sex }\end{array}$ & Occupation & Income \\
\hline General Public & .30 & .00 & .05 & -.09 & -.05 \\
\hline Petit Jurors & .30 & -.04 & .00 & -.14 & -.26 \\
\hline Grand Jurors & .55 & .10 & .07 & -.37 & -.44 \\
\hline
\end{tabular}

The figures for age show large differences of opinion between younger and older people in all three groups sampled, especially in the sample of grand jurors. The correlation table shows that the corresponding correlation coefficients for age are also large and positive $(.30, .30$ and .55 for the general public, petit juror and grand juror samples respectively). The percentages for race and sex show small differences. The corresponding correlation coefficients for race and sex are therefore also small. The greatest difference in attitude by race or sex occurs between whites and nonwhites in the grand juror sample, where eleven percent more nonwhites than whites agreed with the statement. Similarly, the largest correlation, .10, appears for the nonwhite race variable in the grand juror sample. (The negative sign preceding the correlation coefficient of -.04 for the nonwhiterace variable in the petit juror sample indicates that in that sample, as opposed to the other nonwhite samples, fewer nonwhites than whites agreed with Statement 6.)

The percentage figures for occupation and income show that

205. In this context, positive correlations mean that older people agree more than younger people, nonwhites more than whites, females more than males, higher-occupational-status persons more than lower-occupational-status persons, and high-income persons more than lowincome persons. Negative correlations mean the opposite.

Correlations or regression coefficients must be approximately .15 to be significant at the .05 level in the general public and petit juror samples. In the smaller grand juror sample, correlations must be about .20 to be significant at the .05 level. 
these two variables are more strongly related to attitude than are race and sex. For example, in the grand juror sample, all of the operatives and laborers agreed with Statement 6, while only thirty-four percent of the professional and technical workers agreed. It is somewhat difficult to interpret these data, however, because income and occupation have somewhat inconsistent effects and because each of these two social characteristics has a large number of categories. ${ }^{206}$ Correlation coefficients therefore are particularly useful in summarizing these data. The correlation coefficients for occupation and income are all negative, indicating that persons of lower occupational status and lower income agreed more often than persons of higher occupational status and higher income. The correlation coefficients for occupation and income also vary considerably among the three samples. They are negligible in the general public sample, moderate in the petit juror sample, and strong in the grand juror sample. Viewing the correlation coefficients as a whole, it is clear that age correlates more strongly and consistently with attitudes than do any of the other variables.

Table 8 shows the correlation coefficients for all five variables and all twenty-one opinion statements for each of the three samples. The brief phrases included in the table summarize the original statements. Most of the opinion statements were phrased in a "conservative" manner; the exceptions are numbers $1,7,12$, and 23 , which are identified by footnote "a" in the table. The negative correlation coefficients of age for these four statements are explained by the fact that older people generally agreed with them less often than younger people.

Table 8 is divided into three sections: (A) general public, (B) petit jurors, and (C) grand jurors. The largest correlation coefficient for each statement is starred in order to highlight the relative importance of each of the five variables. In the sample of the general public, age correlates most strongly with twelve of the twenty-one opinion statements. Income correlates most strongly with three statements, race, sex, and occupation with two statements each. Thus, in this sample, attitudes correlate much more strongly with age than with any other variable.

206. A good example of the inconsistency of these effects occurs in the general public sample for the occupational variable. Although the percentage difference listed is $-1 \%$, the difference is $-27 \%$ if craftsmen and foremen (75\%) are compared with clerical workers $(48 \%)$, and the difference is $+24 \%$ if service workers $(58 \%)$ are compared with managers and administrators $(82 \%)$. 
TABLE 8

Correlations Between Five Social Characteristics and

Twenty-One Opinion Statements in Samples of the General Public, Petit Jurors, and Grand Jurors

A. General Public

\begin{tabular}{|c|c|c|c|c|c|c|}
\hline & Opinion Statements & Age & $\begin{array}{l}\text { Nonwhite } \\
\text { Race }\end{array}$ & $\begin{array}{l}\text { Female } \\
\text { Sex }\end{array}$ & $\begin{array}{l}\text { Occu- } \\
\text { pation }\end{array}$ & Income \\
\hline 1. & Better to let guilty go free ${ }^{a}$ & -.10 & .03 & $-.18^{*}$ & .16 & .15 \\
\hline 2. & Police should use force & $.34^{*}$ & -.13 & .08 & -.03 & -.11 \\
\hline 3. & Capital punishment effective & $.26^{*}$ & -.04 & .06 & -.20 & -.12 \\
\hline 4. & Courts too easy on young & $.32 *$ & .10 & .00 & -.06 & -.02 \\
\hline & Police should arrest suspicious & $.32^{*}$ & .01 & .11 & -.31 & -.21 \\
\hline & $\begin{array}{l}\text { Taking fifth amendment is } \\
\text { hiding }\end{array}$ & $.30^{*}$ & .00 & .05 & -.09 & -.05 \\
\hline & $\begin{array}{l}\text { Police often lie for one } \\
\text { another }^{2}\end{array}$ & -.14 & $.15^{*}$ & -.08 & 0.0 & .01 \\
\hline 8. & Older people wiser & $.23^{*}$ & .01 & .02 & -.12 & -.08 \\
\hline 9. & Young respect law less & $.31^{*}$ & .12 & .08 & .00 & -.16 \\
\hline 10. & Several charges, guilty of one & $.27^{*}$ & .03 & .19 & -.21 & -.22 \\
\hline 11. & Police arrest with good reason & .21 & $-.29 *$ & .04 & -.15 & -.01 \\
\hline 12. & Innocent are often tried ${ }^{a}$ & -.08 & -.03 & -.04 & -.11 & $-.17^{*}$ \\
\hline 13. & $\begin{array}{l}\text { Obedience to authority } \\
\text { important }\end{array}$ & $.25^{*}$ & .04 & .06 & -.23 & -.24 \\
\hline 14 & $\begin{array}{l}\text { Defendant must prove } \\
\text { innocenceb }\end{array}$ & .15 & .20 & .21 & $-.26^{*}$ & -.23 \\
\hline & $\begin{array}{l}\text { Vote guilty despite lack of } \\
\text { evidence }\end{array}$ & .06 & -.04 & .06 & $-.17^{*}$ & -.08 \\
\hline 19 & Follow DA on indictment & .19 & -.09 & $.23^{*}$ & -.11 & \\
\hline 21 & $\begin{array}{l}\text { Walve right and let DA asK } \\
\text { questions } \\
\text { Change vote to go with }\end{array}$ & .25 & .03 & .12 & -.24 & $-.30^{*}$ \\
\hline & majority & $.26^{*}$ & -.01 & .13 & -.09 & -.20 \\
\hline 22 & $\begin{array}{l}\text { Follow DA since he knows } \\
\text { evidence }\end{array}$ & $.40^{*}$ & -.11 & .18 & -.24 & -.31 \\
\hline 23 & $\begin{array}{l}\text { DAs conceal evidence for } \\
\text { indictment }^{2}\end{array}$ & -.11 & -.03 & .02 & .10 & $-.15^{*}$ \\
\hline 24. & $\begin{array}{l}\text { Should be "older, experienced } \\
\text { people"b }\end{array}$ & $.31^{*}$ & .04 & .01 & -.22 & -.13 \\
\hline
\end{tabular}

-continued-

* Highest correlation coefficient for each statement is starred.

a. These statements were phrased in a "liberal" manner.

b. For statements 14,15 , and 24 , where only two choices were given, the correlation was computed for picking the answer indicated.

Section B of Table 8 shows the same general pattern for the petit jurors. Age correlates most strongly with nine of the twenty-one opinion statements, while income correlates most strongly with five. Race, sex, and occupation show the strongest correlations with only four, one, and two statements, respectively. ${ }^{207}$

Section $\mathrm{C}$ of Table 8 presents the correlation coefficients for grand jurors. Income emerges as the characteristic correlating most

207. Age is starred for Statement 20 in the petit jury sample as having the highest correlation $(.28)$ even though income has a correlation of apparently equal strength $(-.28)$, because age had a slightly stronger correlation before rounding. 
B. Petit Jurors

\begin{tabular}{|c|c|c|c|c|c|c|}
\hline & Opinion Statements & Age & $\begin{array}{c}\text { Nonwhite } \\
\text { Race }\end{array}$ & $\begin{array}{c}\text { Female } \\
\text { Sex }\end{array}$ & $\begin{array}{l}\text { Occu- } \\
\text { pation }\end{array}$ & Income \\
\hline 1. & Better to let guilty go free ${ }^{a}$ & -.04 & .05 & .00 & .12 & $.24^{*}$ \\
\hline 2. & Police should use force & .18 & $-.19^{*}$ & .02 & -.08 & -.09 \\
\hline 3. & Capital punishment effective & .06 & $-.23 *$ & .02 & -.12 & .00 \\
\hline 4. & Courts too easy on young & $.24^{*}$ & -.02 & -.05 & -.21 & -.07 \\
\hline 5. & Police should arrest suspicious & $.29^{*}$ & -.17 & .07 & -.13 & -.28 \\
\hline 6. & $\begin{array}{l}\text { Taking fifth amendment is } \\
\text { hiding }\end{array}$ & $.30^{*}$ & -.04 & .00 & -.14 & -.26 \\
\hline & $\begin{array}{l}\text { Police often lie for one } \\
\text { another }\end{array}$ & -.07 & $.20^{*}$ & .00 & -.07 & .04 \\
\hline 8. & Older people wiser & $.36^{*}$ & .02 & -.07 & -.28 & -.18 \\
\hline 9. & Young respect law less & $.33^{*}$ & .00 & .07 & -.21 & -.29 \\
\hline 10. & Several charges, guilty of one & .28 & .04 & .12 & -.21 & $-.33^{*}$ \\
\hline 11. & Police arrest with good reason & $.33^{*}$ & -.18 & .06 & -.25 & -.20 \\
\hline 12. & Innocent are often trieda & .01 & .11 & $-.12^{*}$ & -.02 & -.06 \\
\hline 13. & $\begin{array}{l}\text { Obedience to authority impor- } \\
\text { tant }\end{array}$ & .37 & -.08 & -.05 & $-.39^{*}$ & -.32 \\
\hline 14. & $\begin{array}{l}\text { Defendant must prove } \\
\text { innocence }\end{array}$ & .09 & -.06 & .07 & -.10 & $-.28^{*}$ \\
\hline 15. & $\begin{array}{l}\text { Vote guilty despite lack of } \\
\text { evidenceb }\end{array}$ & .06 & -.08 & -.10 & $-.12^{*}$ & -.11 \\
\hline $\begin{array}{l}19 . \\
20 .\end{array}$ & $\begin{array}{l}\text { Follow DA on indictment } \\
\text { Waive right and let DA ask }\end{array}$ & .12 & $-.16^{*}$ & .12 & -.12 & -.06 \\
\hline 21. & $\begin{array}{l}\text { questions } \\
\text { Change vote to go with }\end{array}$ & $.28^{*}$ & -.17 & .08 & -.16 & -.28 \\
\hline & $\begin{array}{l}\text { majority } \\
\text { Follow DA since he knows }\end{array}$ & .20 & -.10 & .01 & -.23 & $-.26^{*}$ \\
\hline 23. & $\begin{array}{l}\text { evidence } \\
\text { DAs conceal evidence for }\end{array}$ & $.26^{*}$ & -.12 & .03 & -.24 & -.21 \\
\hline & $\begin{array}{l}\text { indictment } \\
\text { Should be "older, experienced }\end{array}$ & -.05 & .01 & .08 & .16 & $.20^{*}$ \\
\hline & people"b & $.29 *$ & -.03 & .13 & -.16 & -.18 \\
\hline
\end{tabular}

-continued-

* Highest correlation coefficient for each statement is starred.

a. These statements were phrased in a "liberal" manner.

b. For statements 14,15 , and 24 , where only two choices were given, the correlation was computed for picking the answer indicated.

strongly with 10 of the statements. Age correlates most strongly with seven statements, while race, sex, and occupation show the strongest correlations with three, none and one statements respectively. Overall, Table 8 demonstrates that attitudes correlate more strongly with age than with any of the other variables tested.

b. Multiple regression analysis. The correlation analysis provides evidence that age is a more important determinant of these opinions than the other social characteristics. However, correlation analysis is not conclusive, because it considers only two variables at a time (one social characteristic in relation to one opinion statement). The final step of a thorough analysis requires a statistical technique capable of analyzing several variables at a time, that is, a technique which can examine the relationships of all the social characteristics to each opinion statement simultaneously. 
C. Grand Jurors

\begin{tabular}{|c|c|c|c|c|c|c|}
\hline & Opinion Statements & Age & $\begin{array}{c}\text { Nonwhite } \\
\text { Race }\end{array}$ & $\begin{array}{c}\text { Female } \\
\text { Sex }\end{array}$ & $\begin{array}{l}\text { Occu- } \\
\text { pation }\end{array}$ & Income \\
\hline 1. & Better to let guilty go free ${ }^{a}$ & -.06 & .03 & .16 & $.17^{*}$ & .12 \\
\hline 2. & Police should use force & .22 & -.11 & .04 & -.21 & $-.30^{*}$ \\
\hline 3. & Capital punishment effective & .01 & $-.35^{*}$ & -.02 & .02 & -.08 \\
\hline 4. & Courts too easy on young & $.24^{*}$ & -.04 & .00 & -.16 & -.22 \\
\hline $\begin{array}{l}5 . \\
6 .\end{array}$ & $\begin{array}{l}\text { Police should arrest suspicious } \\
\text { Taking fifth amendment is }\end{array}$ & $.35^{*}$ & -.10 & .08 & -.28 & -.31 \\
\hline & $\begin{array}{l}\text { hiding } \\
\text { Police often lie for one }\end{array}$ & $.55^{*}$ & .10 & .07 & -.37 & -.44 \\
\hline & another ${ }^{a}$ & .04 & $.24^{*}$ & -.06 & .16 & 10 \\
\hline 8. & Older people wiser & .45 & .24 & -.00 & -.18 & $-.48^{*}$ \\
\hline 9. & Young respect law less & $.43^{*}$ & .18 & .07 & -.07 & -.37 \\
\hline 10. & Several charges, guilty of one & 32 & .12 & .07 & -.10 & $-.35^{*}$ \\
\hline 11. & Police arrest with good reason & .09 & -.09 & .05 & -.18 & $-.26^{*}$ \\
\hline 12. & Innocent are often tried ${ }^{a}$ & $.19^{*}$ & .08 & .09 & -.08 & -.17 \\
\hline 13. & $\begin{array}{l}\text { tant } \\
\text { Defendant must prove }\end{array}$ & $.52^{*}$ & .12 & .08 & -.30 & -.38 \\
\hline & $\begin{array}{l}\text { Defendant must prove } \\
\text { innocence } \\
\text { Vote guilty despite lack of }\end{array}$ & .19 & .10 & .09 & -.22 & $-.26^{*}$ \\
\hline & $\begin{array}{l}\text { Vote guilty despite lack of } \\
\text { evidenceb }^{b}\end{array}$ & .33 & .06 & 15 & -.34 & $-.37^{*}$ \\
\hline 19. & Follow DA on indictment & .14 & -.13 & .00 & -.10 & $-.25^{*}$ \\
\hline 21. & $\begin{array}{l}\text { Waive rignt and let DA ask } \\
\text { questions } \\
\text { Change vote to go with }\end{array}$ & .35 & 17 & .06 & -.21 & $-.43^{*}$ \\
\hline 22. & $\begin{array}{l}\text { majority } \\
\text { Follow DA since he knows }\end{array}$ & .38 & .23 & 17 & -.24 & $-.50^{*}$ \\
\hline 23. & $\begin{array}{l}\text { evidence } \\
\text { DAs conceal evidence for }\end{array}$ & .31 & .11 & .06 & -.28 & $-.45^{*}$ \\
\hline 24. & $\begin{array}{l}\text { indictment } \\
\text { Should be "older, experienced }\end{array}$ & -.03 & $.22 *$ & .03 & -.10 & -.02 \\
\hline & people"b & $.33^{*}$ & .13 & -.09 & -.11 & -.23 \\
\hline
\end{tabular}

* Highest correlation coefficient for each statement is starred.

a. These statements were phrased in a "liberal" manner.

b. For statements 14, 15, and 24, where only two choices were given, the correlation was computed for picking the answer indicated.

The need for a multivariate analysis can be shown by a simple example. The correlations have shown that occupational status and family income generally are negatively correlated with the conservatively phrased opinion statements: that is, persons with higher-status occupations less often agree with such statements than persons with lower-status occupations, and higher-income persons less often agree than lower-income persons. However, occupational status is itself positively correlated with income-persons with higher occupational status generally have higher incomes than persons with lower occupational status. ${ }^{208}$ Therefore, the fact that persons of higher occupational status less often agree with these statements may be due either to their higher occupational status, or to their higher income, or to

208. For the sample of the Queens County general public, the correlation between occupation and income was computed to be .23 . The correlations were even higher for the petit juror (.33) and the grand juror (.46) samples. 
both factors. A two-variable technique like correlation analysis cannot distinguish that part of a correlation between a social characteristic and an opinion statement which is actually due to the characteristic, and that part which is due to the other social characteristics with which the first characteristic is correlated. Only a multivariate technique can identify the independent effects of each social characteristic on the opinions expressed in the survey.

Of the several different multivariate techniques, multiple regression analysis is considered the most widely applicable and statistically efficient. ${ }^{209}$ A multiple regression analysis therefore was performed for each of the twenty-one opinion statements using the regression routine in the Statistical Package for the Social Sciences. ${ }^{210}$ Multiple regression analysis has both similarities to and differences from correlation analysis. Like correlation analysis, multiple regression analysis produces a single number, called a standardized regression coefficient, for each of the social characteristics in relation to an opinion statement. Regression coefficients, like correlations, have algebraic signs which indicate the nature of the relationship. Once again, positive regression coefficients mean that older people, nonwhites, females, persons with higher occupational status, and persons with higher income agree with a statement more often than their counterparts. The most important difference between multiple regression coefficients and correlation coefficients is that the regression coefficient for a social characteristic represents the unique relationship of that characteristic to the opinion statement after the relationships of the other social characteristics have been controlled. for. This difference is not apparent from looking at a table of multiple regression coefficients, but it means that multiple regression coefficients are statistically more sophisticated than correlation coefficients.

A multiple correlation coefficient $(R)$, and the square of that statistic $\left(\mathrm{R}^{2}\right)$, called "R-square," are customarily presented in association with a multiple regression analysis. The multiple correlation coefficient, $R$, shows the total correlation of all five social characteristics with the opinion statement. It varies between 0 and 1.00 and employs no algebraic sign. The $\mathrm{R}^{2}$ statistic is the only one which can be given a common-sense percentage interpretation. It shows the percent of the variation in response to each opinion statement which is explained or accounted for by the five social characteristics in combination. As is not uncommon in social science research, the $\mathrm{R}^{2}$ statistics are fairly low, indicating that many other social and psy-

209. See H. BlalOCK, supra note 203, at 357.

210. N. Nie, C. Hull, J. Jenkins, K. Steinbrenner, \& D. Bent, Statistical Package For THE Social ScIENCES (2d ed. 1975). 
chological characteristics in addition to the five studied also affect these opinion statements.

The multiple regression analyses for the twenty-one opinion statements, including the five standardized regression coefficients and the $R$ and $R^{2}$ statistics, are shown in Table 9. The highest regression coefficient for each opinion statement is starred to facilitate evaluation of the results.

TABLE 9

Regression ANalyses of Five Social Characteristics and Twenty-One Opinion Statements in Samples of the General Public, Petit Jurors, and Grand Jurors

\begin{tabular}{|c|c|c|c|c|c|c|c|c|}
\hline & A. & Stan & ardized & Regressic & on Coeffi & icients & & \\
\hline & Opinion Statements & Age & $\begin{array}{l}\text { Non- } \\
\text { white } \\
\text { Race }\end{array}$ & $\begin{array}{l}\text { Female } \\
\text { Sex }\end{array}$ & $\begin{array}{l}\text { Occu- } \\
\text { pation }\end{array}$ & Income & $\mathbf{R}$ & $\mathrm{R}^{2}$ \\
\hline 1. & uilty go free ${ }^{a}$ & -.06 & .08 & $-.17^{*}$ & .15 & .08 & .27 & .08 \\
\hline 2. & Police should use force & $.32 *$ & -.13 & .06 & -.01 & -.07 & .37 & .14 \\
\hline 3. & Capital punishment effective & $.24^{*}$ & -.06 & .04 & -.18 & -.05 & .33 & .11 \\
\hline 4. & Courts too easy on young & $.33^{*}$ & .11 & -.03 & -.01 & .02 & .34 & .12 \\
\hline 5. & $\begin{array}{l}\text { Police should arrest suspi- } \\
\text { cious }\end{array}$ & $.28^{*}$ & -.03 & .08 & -.26 & -.11 & .45 & .20 \\
\hline 6. & $\begin{array}{l}\text { Taking fifth amendment is } \\
\text { hiding }\end{array}$ & $.29^{*}$ & .00 & .03 & $.0 r$ & .00 & .30 & .09 \\
\hline 7. & $\begin{array}{l}\text { Police often lie for one } \\
\text { anothera }\end{array}$ & -.12 & $.16^{*}$ & -.09 & .0 & -.02 & .22 & .05 \\
\hline 8. & Older & $.22^{*}$ & .01 & .00 & -.09 & -.03 & .26 & .07 \\
\hline 9. & law less & $.30^{*}$ & .13 & .01 & .08 & -.14 & .36 & .13 \\
\hline 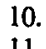 & Several charges, guilty of one & $.22^{*}$ & -.01 & .16 & -.17 & -.13 & .40 & .16 \\
\hline & $\begin{array}{l}\text { Polic } \\
\text { son }\end{array}$ & 18 & -.32 & .07 & -.20 & .04 & .41 & .17 \\
\hline 12. & Innocent are often tried ${ }^{a}$ & -.11 & -.05 & -.06 & -.08 & $-.18^{*}$ & .23 & .05 \\
\hline & te authority & $.21^{*}$ & .02 & .02 & -.17 & -.17 & .37 & .14 \\
\hline & $\begin{array}{l}\text { Defendant must prove } \\
\text { innocence }\end{array}$ & .11 & .15 & .17 & $-.20^{*}$ & -.14 & .41 & .17 \\
\hline & $\begin{array}{l}\text { Vote guilty despite lack of } \\
\text { evidenceb }^{b}\end{array}$ & .0 & -.0 & .0 & $-.17^{*}$ & -.03 & , & .04 \\
\hline & Follow DA on indictment & .15 & -.13 & $.21^{*}$ & -.09 & -.13 & .35 & .12 \\
\hline & $\begin{array}{l}\text { Waive right and let DA ask } \\
\text { questions }\end{array}$ & .20 & -.01 & .07 & -.18 & $-.23^{*}$ & .41 & .17 \\
\hline & $\begin{array}{l}\text { Change vote to go with } \\
\text { majority }\end{array}$ & $.24^{*}$ & -.02 & .09 & -.04 & -.15 & .33 & .11 \\
\hline & $\begin{array}{l}\text { Follow DA since he knows } \\
\text { the evidence }\end{array}$ & $.35^{*}$ & -.15 & .14 & -.18 & -.22 & .54 & .29 \\
\hline J. & l evidence for & & & & & & & \\
\hline & ind & -.12 & .03 & .01 & .13 & & .24 & .06 \\
\hline & experienced people"b & $.29^{*}$ & .03 & -.01 & -.17 & -.06 & .37 & .13 \\
\hline
\end{tabular}

* Highest regression coefficient for each statement is starred.

a. These statements were phrased in a "liberal" manner.

b. For statements 14,15 , and 24 , where only two choices were given, the regression coefficient was computed for picking the answer indicated. 
Overall, Table 9 confirms the conclusion that age is the most important social characteristic in relation to the opinion statements in the general public and the petit juror samples and that it is second in importance to income in the sample of grand jurors. In the sample of the general public, age has the strongest relationship to twelve of the twenty-one statements; in the petit juror sample, age has the highest regression coefficient for nine of the statements. In the grand juror sample, however, income has the strongest relationship to nine statements, ${ }^{211}$ while age is the most important characteristic for seven.

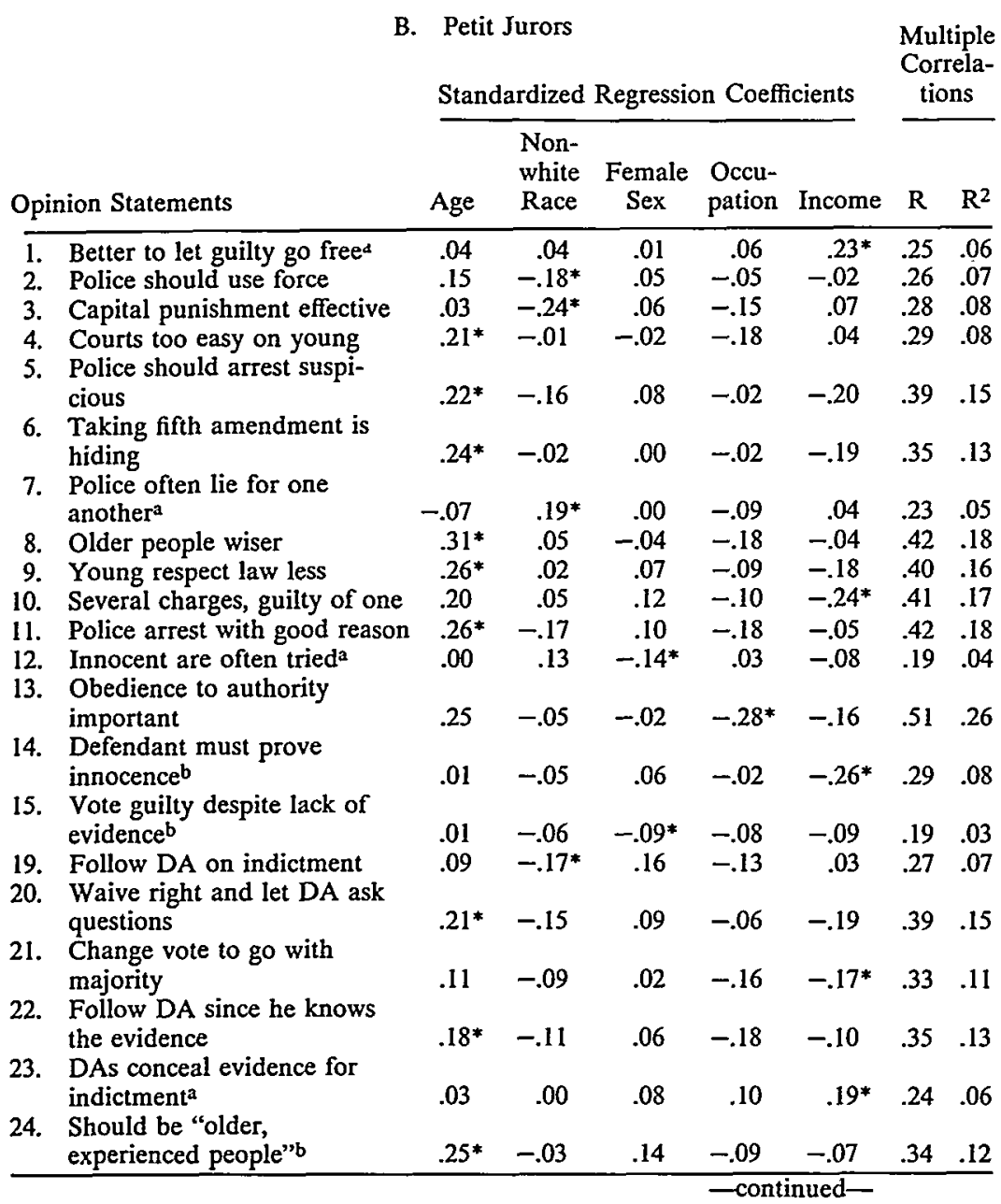

* Highest regression coefficient for each statement is starred.

a. These statements were phrased in a "liberal" manner.

b. For statements 14,15, and 24 , where only two choices were given, the regression coefficient was computed for picking the answer indicated.

211. The data in Table 9 support the additional conclusion that occupation and income groups are cognizable. The multiple regression coefficients for occupation and income show a strong relationship between these characteristics and attitudes for many of the opinion statements in all three samples. Other recent studies also have shown that members of different 
C. Grand Jurors

Standardized Regression Coefficients tions

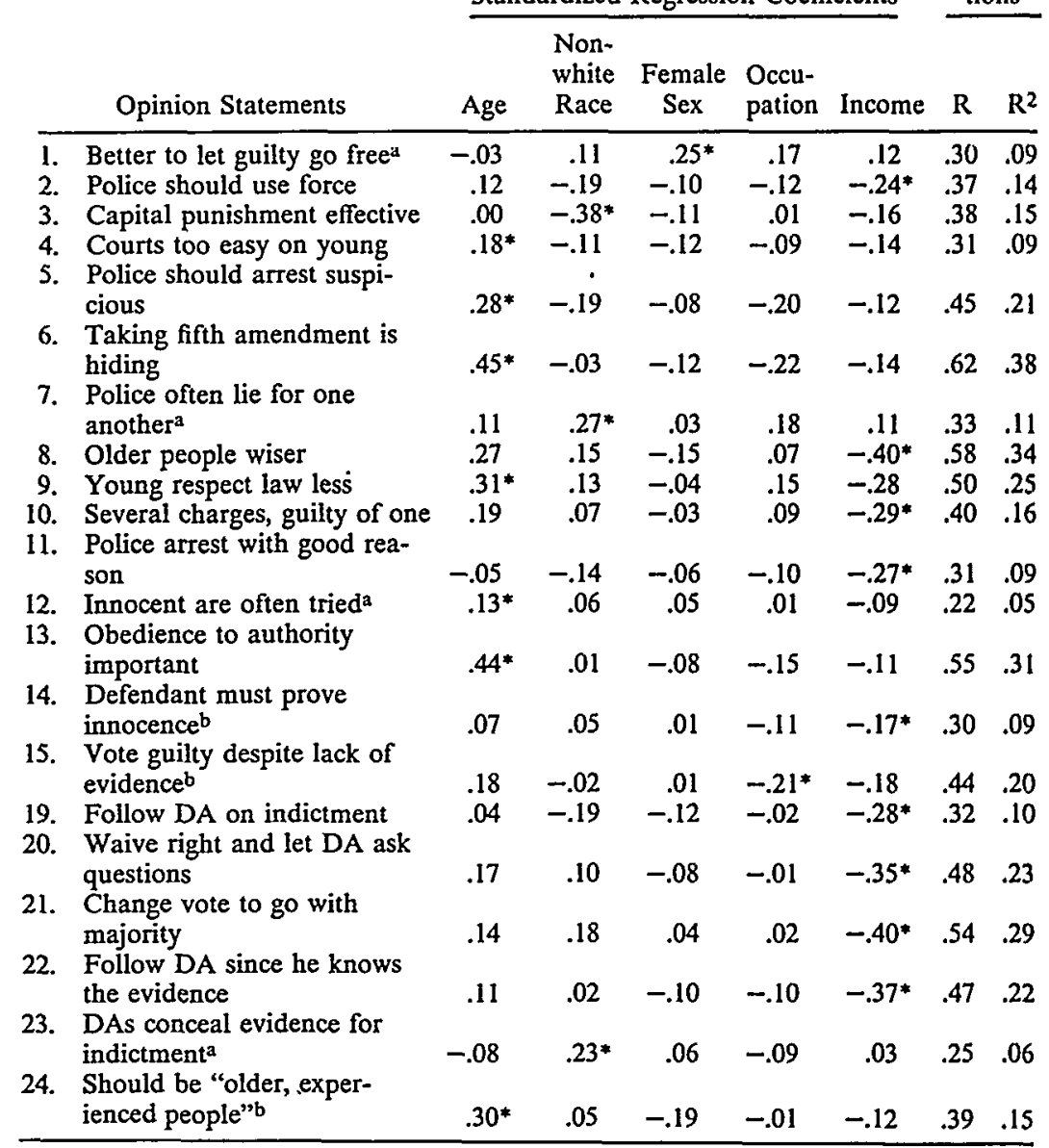

* Highest regression coefficient for each statement is starred.

a. These statements were phrased in a "liberal" manner.

b. For statements 14,15 , and 24 , where only two choices were given, the regression coefficient was computed for picking the answer indicated.

occupational and income groups differ in knowledge, expertise, and attitudes on matters of importance in jury service.

One researcher interviewed jurors following trial in 23 cases. He found that particularized occupational knowledge or experience appeared to have affected the decision in eight of the 16 civil cases studied and that occupational bias played a part in four of the seven criminal cases studied. Broeder, Occupational Expertise and Bias as Affecting Juror Behavior: A Preliminary Look, 40 N.Y.U.L. Rev. 1079 (1965).

Data presented in SOURCEBOOK OF CRIMINAL JUSTICE STATISTICS, supra note 197, support the conclusion that income groups are cognizable. Nationwide samples were questioned about criminal justice issues, and the results show a strong relationship between attitudes and income. In 1975, respondents in 13 selected American cities were asked: "How safe do you feel or would you feel about being out alone in your neighborhood during the day?" Of those with incomes under $\$ 3,000$ and those with incomes from $\$ 3,000$ to $\$ 5,000$, only $31 \%$ and $32 \%$ respectively answered "very safe." By contrast, of those with incomes from $\$ 15,000$ to $\$ 20,000$, from $\$ 20,000$ to $\$ 25,000$, and over $\$ 25,000$, fully $53 \%, 56 \%$, and $61 \%$ respectively offered that answer. Id. at 304 table 2.8 . 
The multiple regression analysis thus shows that age is the most important of these social characteristics in relation to attitudes which are important in jury deliberations. The stronger correlations for age are not the accidental result of its correlations with the other social characteristics. Rather, they show the greater impact of age upon a person's opinion, independent of his or her sex, race, occupation, or income.

In sum, the data support the following conclusions. First, there are significant differences in attitudes between younger and older people in all three samples for nearly all of the twenty-one opinion statements. Second, the differences in attitudes generally progress systematically from the youngest to the oldest age groups. Third, in most cases, the greatest differences in attitudes occur between the youngest and oldest age groups. Fourth, the correlations between attitudes and age are stronger than the correlations between attitudes and race, sex, occupation or income. Fifth, these stronger correlations are not due to the correlation of age with one of the other social characteristics mentioned; age independently affects attitude.

\section{CONCLUSION}

In the 1940s, courts assumed that a broad range of groups were cognizable. The danger of bias from the exclusion of an identifiable group and the possibility that its exclusion would cause a distinct "fflavor" to be lost and would undermine the cross-sectional ideal warranted the recognition that a group was cognizable. More recently, courts have required proof that groups satisfy newly articulated criteria of cognizability. By too stringently applying these criteria, courts have insulated discrimination in jury selection from effective challenge.

Even by modern standards, Part III above demonstrates that young adults are cognizable. They are distinct and identifiable; they share attitudes and experiences which cannot be represented adequately by their elders; and their underrepresentation on juries results in bias against young criminal defendants and distorts the deliberative process. In light of this convincing evidence, courts

Another group of respondents was asked whether or not they agreed that law enforcement agencies should be tougher than they are now in dealing with crime and lawlessness. Only $73 \%$ of those with incomes under $\$ 3,000$ agreed, compared to $88 \%$ of those with incomes over $\$ 15,000$. Id . at 316 table 2.29 . Similarly strong relationships between income and attitudes were found in questions dealing with the death penalty and legalization of marijuana. Generally, lower-income people were less likely to favor the use of the death penalty or legalization of marijuana than higher-income people. $I d$. at 327 table 2.61, 342 table 2.91 . 
should take judicial notice that young adults are cognizable, without requiring proof case by case. ${ }^{212}$

Although young adults meet the modern test, other groups might be unable to present as clear or dramatic evidence of their cognizability. In such cases, courts should reconsider the strict application of cognizability criteria. If a community group is sufficiently large and can be identified easily by questions on jury-qualification questionnaires, it should not be denied recognition simply because the boundaries of the group are somewhat arbitrary. Moreover, courts should use their common sense in determining whether a given group shares common attitudes and experiences which cannot be represented adequately by others. Although courts reasonably can ask those seeking to establish the cognizability of particular groups to submit proof on the issue, they should not necessarily require movants to submit proof as complex or sophisticated as that presented above.

Of course, the state has an administrative interest in selecting juries through flexible methods. But courts can protect that interest when evaluating the merits of a jury selection complaint. To invoke that interest as a justification for denying cognizability is irrational, for it broadly and unnecessarily disqualifies entire groups from any judicial help in securing representation on juries.

If additional groups are recognized, the result will be more representative juries. As the Supreme Court stated in Smith v. Texas, "it is part of the established tradition in the use of juries as instruments of public justice that the jury be a body truly representative of the community."213 Continued failure to extend cognizability to com- munity groups can only undermine the vitality and integrity of the jury as a democratic institution.

212. In exceptional cases, courts might be justified in refusing to take judicial notice of the cognizability of the young. For example, in an isolated, conservative, rural community, the young might be less likely to have distinct attitudes than in a more urban setting. In such a community, the court could properly require specific proof of the attitudes of the community's young adults. But this Article's argument for cognizability has been sufficiently strong that these exceptions should be rare.

213. 311 U.S. at 130. 


\section{APPEndix A: SuRvey Methodology}

The survey was designed to elicit attitudes of a cross section of the Queens County population and to determine whether there are significant variations in attitude among people in age, sex, race, occupation, and income groups concerning the criminal justice system and petit and grand jury service. A questionnaire (Exhibit 1) was developed by Eric Swanson, Elissa Krause, Donald Zeigler, and Jay Schulman, and consultation was provided by Richard Christie and Robert Buckhout. Questions were included which would reflect a wide range of attitudes toward law and the legal system and toward petit and grand jury service.

Names of persons to be interviewed were taken from three sources-the Queens County petit jury rolls, grand jury rolls and the telephone book. Although both petit and grand jurors in Queens County ultimately come from the general population and grand jurors are selected from among persons qualified to serve as petit jurors, the selection procedures for both petit and grand jurors involve many subjective judgments by personnel of the County Clerk's office. Because the selection procedures are not random, it could not be assumed that the attitudes of petit jurors are representative of the attitudes of the general population or that the attitudes of grand jurors are representative of the attitudes of either of these groups. In fact, the survey results show significant disparities in response to many of the opinion statements in the questionnaire among the three groups. Only by sampling all three groups could a complete picture of their attitudes emerge.

Most interviewers were Legal Aid attorneys and law students who were summer volunteers with the Legal Aid Society. Interviewers were trained by Eric Swanson and other members of the staff of the National Jury Project, including Elissa Krause and Lee O'Brien. Interviews of petit jurors and members of the general public were conducted between approximately 6:00 and 9:30 p.m. Monday through Thursday for a four-week period commencing Monday, July 26, 1976. The grand jurors were surveyed during the evening hours from September 7 to 9, 1976.

\section{Random Telephone Sample of the General Public}

The sample universe consisted of all persons between the ages of 18 and 75 living in a household with a telephone. Approximately 640 telephone numbers were taken at random from the 1975-1976 Queens telephone directory. The numbers chosen were not called. 
Instead, they became "seeds" for the development of new numbers. The final phone sample was derived by adding one digit to the seed numbers (e.g., 978-0970 became 978-0971). This process effectively randomized the numbers and eliminated possible bias due to the fact that some eligible respondents have unlisted phone numbers.

Interviewers were given computer grids (Exhibit 2) (t) $^{\mathrm{Al}}$ totermine which person to interview at each phone number reached. The purpose of the grid was to eliminate any bias by reason of age- or sex-related phone answering patterns and thus insure that the sample was truly random. The interviewers were instructed that upon reaching a household, they should determine the total number of persons between the ages of 18 and 75 in the household and locate this number on the horizontal axis. They should then ask how many of the people in this age group were males and locate this number on the vertical axis. By looking in the box on the grid at the point of intersection, the interviewers would determine which household member to interview-e.g., the "second oldest female," the "youngest male," the "oldest male," etc. Interviewers were instructed to speak only to the person assigned by the grid.

A standard introduction was provided for interviewers to obtain the necessary preliminary identifying information. Interviewers were instructed to record on their call-record sheets all calls except disconnected numbers reached during the course of the random telephone survey. A total of 232 interviews was completed.

\section{Petit Juror Sample}

The sample universe consisted of the approximately 200,000 persons on the petit jury rolls in Queens County. Individual names were drawn from the set of completed petit jury questionnaires of qualified petit jurors by choosing every twentieth questionnaire. Eight hundred forty-six names were drawn from file drawers labeled 1973; 845 names were taken from file drawers labeled 1974; and 823 names were drawn from file drawers labeled 1975 . The name, age, and phone number of each person selected were written on a threeby-five index card.

The sample was then stratified as follows. The index cards were sorted into decades; that is, cards of people in their 20s were placed together, cards of people in their 30 s were placed together, and so forth. There were no persons aged 18 or 19. Cards for people over

A1. Exhibit 2 is an example of a grid. A large number of different grids were generated by a computer in order to randomize the selection of respondents. 
age 75 were excluded because they are not eligible for jury duty. A subsample of 300 names was drawn at random from six age groups in numbers sufficient to insure that each age group was represented iin proportion to its numbers in the population as a whole. The appropriate percentage to be chosen from each age group was determined from 1970 census data. The percentage chosen from each age group was as follows:

$$
\begin{array}{llr}
20 s-22.2 \% & 40 s-19.7 \% & 60 s-16.0 \% \\
30 s-15.6 \% & 50 s-20.3 \% & 70-75-6.2 \%
\end{array}
$$

Sampling was also controlled so that equal numbers of persons from each of the years 1973, 1974, and 1975 were included.

Interviewers were given the index card showing the respondent's name, phone number, and age. They were instructed to ask for the respondent by name, confirm that they had the right person, and interview no one else. Two hundred twenty-nine interviews were completed from the petit-jury-pool sample.

\section{Grand Juror Sample}

The sample of grand jurors came from two sources. The first source was the Queens County Grand Jurors Liable Register for 1975. Data had previously been collected by the Legal Aid Society on the race, sex, occupation, and age of every third person on that Register. However, attempts to contact these people by telephone revealed that there were far too few women, nonwhites, and young people in this sample to draw reliable conclusions. Additional names of people in these specific categories were drawn from the 1974 Liable Register to complete the survey. This process of oversampling ensured that women, nonwhites, and young people were surveyed in sufficient numbers so that the answers obtained were typical of people in these groups. Subsequently, these oversampled groups were weighted back to their original proportions so that the overall survey results would accurately reflect the attitudes of Queens County grand jurors as a whole. Appendix B describes this and other standard statistical weighting procedures utilized in the study. A total of 118 grand juror interviews was completed. 


\section{EXHIBIT 1}

INTERVIEWER'S NAME: DATE:

RESPONDENT'S NAME: PHONE NO:

\section{SOURCE:}

Hello Mr./Ms. . My name is I'm working with the Legal Aid Society of New York. We're doing a public opinion survey of peoples' attitudes towards the criminal justice system. The court has granted us permission to conduct this survey. I'd like to take a few minutes of your time to ask your opinions. Everything you say will be kept completely confidential. OK?

(If appropriate: refer to sampling grid.)

For the first set of questions I'm going to read some opinion statements. For each statement would you please tell me whether you agree strongly, agree somewhat, disagree somewhat or disagree strongly. There are no right or wrong answers. We're only interested in your opinions.

\section{INSTRUCTIONS TO INTERVIEWERS:}
Coding: 1. agree strongly
2. agree somewhat
3. disagree somewhat
4. disagree strongly
DO NOT
READ. 9. don't know

Repeat scale as often as necessary until you are sure that respondent has it clearly. If respondent only answers "agree" or "disagree" be sure to ask "somewhat or strongly?"

\section{CIRCLE CORRECT NUMBER}

1. It is better to let some guilty people go free rather than risk sending innocent people to jail.

2. Police should not hesitate to use force to maintain order.

$\begin{array}{lllll}1 & 2 & 3 & 4 & 9\end{array}$

$\begin{array}{lllll}1 & 2 & 3 & 4 & 9\end{array}$

3. Capital punishment is more effective than a life sentence in keeping people from committing murder.

4. The courts allow young people to get away with too much too easily.

5. Police should be allowed to arrest and question suspicious looking persons to determine whether they have been up to something illegal.

$\begin{array}{lllll}1 & 2 & 3 & 4 & 9\end{array}$

$\begin{array}{lllll}1 & 2 & 3 & 4 & 9\end{array}$

6. A witness who takes the fifth amendment is probably hiding his or her guilt of a crime.

7. Police will often lie to cover up for one another.

8. In tough situations, older people almost always make wiser decisions than younger people. $\begin{array}{lllll}1 & 2 & 3 & 4 & 9\end{array}$

$\begin{array}{lllll}1 & 2 & 3 & 4 & 9\end{array}$

$\begin{array}{lllll}1 & 2 & 3 & 4 & 9\end{array}$

$\begin{array}{lllll}1 & 2 & 3 & 4 & 9\end{array}$ 
9. Young people have less respect for law than older people.

10. A person accused of several different crimes is probably guilty of at least one of them.

11. The police don't make arrests unless they have good reason to believe that a crime has been committed.

$\begin{array}{lllll}1 & 2 & 3 & 4 & 9\end{array}$

12. Too often, the government brings people to trial who are really not guilty.

$\begin{array}{lllll}1 & 2 & 3 & 4 & 9\end{array}$

13. Obedience to authority is the most important virtue children should learn.

$\begin{array}{lllll}1 & 2 & 3 & 4 & 9\end{array}$

NOW I HAVE A FEW QUESTIONS ON THE JURY SYSTEM.

14. In criminal cases, the judge instructs the jury that the defendant must be considered innocent unless proven guilty. However, many people think that a defendant has the responsibility to prove his or her innocence. If you were a member of a jury in a criminal case, would you follow the judge's instructions or would you want the defendant to prove innocence?

1. follow judge's instructions

2. defendant must prove innocence

15. If you were a member of a jury in a criminal case and truly believed that the person on trial was guilty but the evidence didn't prove it, would you vote to find the person guilty or not guilty?

1. guilty 2. not guilty

16. Have you ever been called for jury service?

1. yes-GO TO Q. $16 \mathrm{~A}$

2. no-skip to Q. 17

16A. Did you actually serve on a jury?
1. yes
2. no
8. doesn't apply

17. Have you heard of a grand jury?

1. yes-GO TO Q. 18

2. no-skip Q. 18.

18. Can you tell me in your own words what a grand jury does?

PROBE ONCE

INTERVIEWER: READ DESCRIPTION OF GRAND JURY TO ALL RESPONDENTS.

To put it briefly, this is what a grand jury does-

The grand jury does not decide whether a person is guilty or innocent. Rather, the District Attorney presents his case and the grand jury decides whether he has enough evidence to make a person stand trial on criminal charges. A judge is not present at a grand jury proceeding. [When the grand jury decides that someone should stand trial, that is called an indictment.] 
Would you agree or disagree with the following statements?

INTERVIEWER: AFTER EACH RESPONSE ASK, "SOMEWHAT OR STRONGLY?" and CIRCLE THE CORRECT NUMBER. .

19. If a District Attorney strongly recommends an indictment, grand jurors should go along with the recommendation.

20. Grand jurors rarely need to exercise their right to ask questions of witnesses because they can rely on the District Attorney to ask all necessary questions.

21. During deliberations, if one grand juror disagrees with the rest of the jurors that person should change his or her vote to go along with the majority.

22. Since the District Attorney is more familiar with the evidence the grand jury should always follow his recommendations.

23. District Attorneys sometimes conceal evidence from a grand jury in order to get an indictment.

24. Do you think Society would be better served if the grand jury represented all segments of the community or if it was composed of older, more experienced people?

25. WHY?
1. all segments
2. older, experienced people
$\begin{array}{lllll}1 & 2 & 3 & 4 & 9\end{array}$

NOW I'M SUPPOSED TO ASK YOU A FEW MORE BACKGROUND QUESTIONS FOR COMPARISON PURPOSES ONLY.

26. In what year were you born?

27. What kind of work do you do?

What industry do you work in?

IF HOUSEWIFE, STUDENT, UNEMPLOYED OR RETIRED, FIND OUT PAST JOB OR PART-TIME WORK.

28. 1. Under $\$ 5,000$

2. Between $\$ 5,000$ and $\$ 10,000$

3. Between $\$ 10,000$ and $\$ 15,000$

4. Between $\$ 15,000$ and $\$ 20,000$

5. Between $\$ 20,000$ and $\$ 25,000$

6. Over $\$ 25,000$

29. We are all Americans, but what country did your family originally come from?

Is English your native language?
1. yes
2. no

30. How often do you attend religious services?

1. more than once a week

2. weekly

3. several times a month. 
4. once a month or less

5. never

31. What is your race?

THANK YOU FOR YOUR PARTICIPATION.

FILL IN AFTER INTERVIEW IS COMPLETED.

AGE SEX

\section{ExHIBIT 2}

\begin{tabular}{crrrrrrrrr} 
Page 855 & \multicolumn{10}{c}{ Seed $=421,637$} \\
Eligible & \multicolumn{10}{c}{ Number of Eligible Respondents } \\
Males & 2 & 3 & 4 & 5 & 6 & 7 & 8 \\
0 & YF & 2 OF & YF & 3 OF & YF & OF & 4 OF \\
1 & F & YF & 2 OF & 2 OF & M & 2 YF & M \\
2 & YM & OM & OM & YM & OM & 3 OF & OM \\
3 & & OM & YM & 2 OM & YF & 2 YF & 2 OF \\
4 & & & YM & OM & OF & 2 YM & OF \\
5 & & & & YM & OM & 2 OM & 3 OM \\
6 & & & & & 3 YM & YM & YM \\
7 & & & & & & 3 OM & 3 OM \\
8 & & & & & & & YM
\end{tabular}

Key: $O=$ Oldest $\quad Y=$ Youngest

$\mathrm{M}=$ Male $\quad \mathrm{F}=$ Female

$1,2,3, \ldots$ etc. $=$ First, Second, Third $\ldots$ 


\section{Appendix B: Statistical Weighting Procedures}

Because young persons are generally underrepresented, special efforts were made in conducting the public opinion survey to select a disproportionately large number of the young so that results for this group would have greater statistical reliability. Consequently, the percentages of young people in the petit juror and grand juror samples were proportionately larger than the percentages in the actual petit jury and grand jury pools. There were also small differences between the age distribution of the people in the sample of the general public and the age distribution of the adult population of the county as a whole. Thus, before the data could be analyzed, the four age groups in all three samples had to be restored to their correct proportional frequencies. This was done by the standard process of statistical weighting. ${ }^{\mathrm{B} 1}$

Table 10 presents the number and percentage of persons in each age group in the samples before and after weighting. The left column for each sample gives the actual percentage of the respective population, by age group. The middle column lists the number and percentage in each sample before weighting and the right column lists the number and percentage after weighting.

The weighting process can be illustrated by examining the data from the petit juror sample. Of the persons on the petit jury rolls, $13.4 \%$ are between the ages of 18 and 30; however, $18.3 \%$ of the petit jurors sampled were in this age group. Thus, the 18-30 age group was overrepresented in the sample of petit jurors. To correct this overrepresentation, a fractional weight of 0.67 was accorded to each person in the group. The 42 persons were subsequently counted as 28 persons, or $12.3 \%$ of the weighted sample, which is closer to their actual percentage (13.4\%) in the petit jury pool. By contrast, persons between the ages of 61 and 75 constitute $25.6 \%$ of the people in the petit jury pool but only $19.2 \%$ of the petit jurors sampled. To correct this underrepresentation, those in the 61-75 age group were given a weight of 1.36 , restoring them to $25.9 \%$ of the weighted sample.

The weights assigned in the general public and petit juror samples were designed to make the total number of persons in the samples before and after weighting as nearly identical as possible. However, weighting in the grand juror sample presented a special problem requiring a different procedure. People between the ages of

B1. For a general discussion of this process, see N. NIE, C. HULl, J. JENKINS, K. STEINBRENNER, \& D. BENT, supra note 210. 
18 and 30 constitute only $5.3 \%$ of the people on the grand jury rolls. Seventeen of these youngs adults were interviewed, and they constituted $14.4 \%$ of the sample of 118 grand jurors. If they had been given an appropriate fractional weight to correct their overrepresentation, the number of young adults would have been reduced from

TABLE 10

Number and Percentages of Persons in Each Age Group in the Samples of the General Public, Petit Jurors and Grand Jurors Before and After Statistical Weighting

General Public

\begin{tabular}{cc}
\multicolumn{2}{c}{$\begin{array}{c}\text { According to } 1970 \\
\text { Census }\end{array}$} \\
Age & $\%$ \\
\hline $18-30$ & 27.0 \\
$31-45$ & 24.6 \\
$46-60$ & 29.1 \\
$61-75$ & 19.3 \\
\hline
\end{tabular}

\begin{tabular}{|c|c|}
\hline \multicolumn{2}{|c|}{$\begin{array}{c}\text { Survey Sample } \\
\text { (Unweighted) }\end{array}$} \\
\hline No. & $\%$ \\
\hline 69 & 30.8 \\
\hline 63 & 28.1 \\
\hline 51 & 22.8 \\
\hline 41 & 18.3 \\
\hline 224 & 100.0 \\
\hline
\end{tabular}

\begin{tabular}{|c|c|c|}
\hline \multicolumn{3}{|c|}{$\begin{array}{l}\text { Survey Sample } \\
\text { (Weighted) }\end{array}$} \\
\hline Weight & No. & $\%$ \\
\hline 0.88 & 61 & 27.0 \\
\hline 0.88 & 55 & 24.7 \\
\hline 1.28 & 64 & 28.5 \\
\hline 1.05 & 45 & 19.9 \\
\hline & 225 & 100.1 \\
\hline
\end{tabular}

Petit Jurors

\begin{tabular}{|c|c|}
\hline \multicolumn{2}{|c|}{ Petit Jury Rolls* } \\
\hline Age & $\%$ \\
\hline $18-30$ & 13.4 \\
\hline $31-45$ & 21.2 \\
\hline $46-60$ & 39.9 \\
\hline $61-75$ & 25.6 \\
\hline
\end{tabular}

TOTAL $\quad 100.1$

\begin{tabular}{|c|c|}
\hline \multicolumn{2}{|c|}{$\begin{array}{l}\text { Survey Sample } \\
\text { (Unweighted) }\end{array}$} \\
\hline No. & $\%$ \\
\hline 42 & 18.3 \\
\hline 47 & 20.5 \\
\hline 96 & 41.9 \\
\hline 44 & 19.2 \\
\hline 229 & 99.9 \\
\hline
\end{tabular}

\begin{tabular}{ccc}
\multicolumn{3}{c}{$\begin{array}{c}\text { Survey Sample } \\
\text { (Weighted) }\end{array}$} \\
Weight & No. & $\%$ \\
\hline & & \\
0.67 & 28 & 12.3 \\
1.00 & 46 & 19.9 \\
1.00 & 96 & 41.9 \\
1.36 & $\underline{59}$ & $\underline{25.9}$ \\
& $\underline{229}$ & 100.0
\end{tabular}

Grand Jurors

\begin{tabular}{|c|c|c|c|c|c|c|}
\hline \multicolumn{2}{|c|}{ Grand Jury Rolls* } & \multicolumn{2}{|c|}{$\begin{array}{l}\text { Survey Sample } \\
\text { (Unweighted) }\end{array}$} & \multicolumn{3}{|c|}{$\begin{array}{c}\text { Survey Sample } \\
\text { (Weighted) }\end{array}$} \\
\hline Age & $\%$ & No. & $\%$ & Weigh & No. & $\%$ \\
\hline $\begin{array}{l}18-30 \\
31-45 \\
46-60 \\
61-75 \\
\end{array}$ & $\begin{array}{r}5.3 \\
12.5 \\
31.2 \\
51.0 \\
\end{array}$ & $\begin{array}{l}17 \\
25 \\
35 \\
41 \\
\end{array}$ & $\begin{array}{l}14.4 \\
21.2 \\
29.7 \\
34.7 \\
\end{array}$ & $\begin{array}{l}1.00 \\
1.60 \\
2.86 \\
4.00\end{array}$ & $\begin{array}{r}17 \\
39 \\
98 \\
158 \\
\end{array}$ & $\begin{array}{r}5.4 \\
12.6 \\
31.2 \\
50.7 \\
\end{array}$ \\
\hline TOTAL & 100.0 & 118 & 100.0 & & 312 & 99.9 \\
\hline
\end{tabular}

* The figures listing the percentages of people in each age bracket for the petit and grand jury rolls were taken from data gathered earlier by the Legal Aid Society. 
17 to 6 . Because the weighted sample would have been very small, rounding error in computing the weighted number of persons would have interfered seriously with the accuracy of subsequent statistical analysis. To overcome this problem, the 18-30 age group was weighted at 1.00 so that the 17 persons were still counted as 17 . All other age groups were then given weights proportionately greater than 1.00 in order to restore the proper age distribution. This procedure increased the sample size of grand jurors from an actual total of 118 to a weighted total of 312 . Increasing the total sample size in this manner does not alter the results in any way since all the statistics presented depend on relative proportions rather than absolute sample size.

The primary reason for weighting is to insure that the samples properly represent age distribution in the population; however, there were also race and sex disparities between the composition of the samples and the composition of the populations from which the samples were drawn. In a test run, the samples were weighted simultaneously by age, sex, and race, except that petit jurors were weighted only by age and sex since the racial composition of the petit jury rolls was not available. The complete set of correlations between the five social characteristics and the 21 opinion statements was then computed with the samples weighted by all the characteristics. The results were virtually identical to those computed when the samples were weighted only by age. Therefore, all the data presented here are weighted only by age. 
Percentage in Each Category of Five Social CharacterisTICS Giving THE MOST CONSERVATIVE RESPONSE TO TwENTYOne Opinion Statements in Samples of the General Public (GP), Petit Jurors (PJ), and Grand Jurors (GJ)*

\begin{tabular}{|c|c|c|c|c|c|c|c|c|c|c|c|c|c|c|c|c|c|c|c|c|c|c|}
\hline \multicolumn{2}{|c|}{\begin{tabular}{|c|}
$\begin{array}{c}\text { Opinion } \\
\text { Statements }\end{array}$ \\
\end{tabular}} & \multicolumn{4}{|c|}{ Age } & \multicolumn{2}{|c|}{ Race } & \multicolumn{2}{|c|}{ Sex } & \multicolumn{7}{|c|}{ Occupation } & \multicolumn{6}{|c|}{ Income } \\
\hline \multirow{4}{*}{ \#1 } & \multirow{4}{*}{$\begin{array}{l}\text { GP } \\
\text { PJ } \\
\text { GJ }\end{array}$} & \multirow{4}{*}{\begin{tabular}{|l|}
$18-$ \\
30 \\
48 \\
49 \\
44 \\
\end{tabular}} & \multirow{2}{*}{$\begin{array}{l}\begin{array}{l}31- \\
45\end{array} \\
38 \\
\end{array}$} & \multirow{2}{*}{$\begin{array}{l}46- \\
60 \\
48 \\
\end{array}$} & \multirow{2}{*}{$\begin{array}{l}61- \\
75 \\
64\end{array}$} & \multicolumn{2}{|c|}{ 总 } & \multirow{2}{*}{ 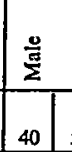 } & \multirow{2}{*}{ 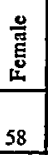 } & \multicolumn{4}{|c|}{ 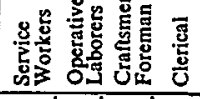 } & \multicolumn{3}{|c|}{ 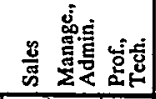 } & t5용 & 密各 & $\begin{array}{l}\text { 항여 } \\
\text { s. }\end{array}$ & 8. & 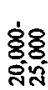 & ํำ \\
\hline & & & & & & 50 & 44 & & & 54 & 58 & 52 & 46 & 67 & 58 & 31 & 62 & 50 & 45 & 50 & 55 & 27 \\
\hline & & & 55 & 45 & 62 & 54 & 44 & 53 & 46 & 57 & 59 & 58 & 65 & 41 & 32 & 45 & 74 & 66 & 65 & 39 & 38 & 41 \\
\hline & & & 36 & 36 & 42 & 39 & 40 & 46 & 27 & 37 & 50 & 48 & 44 & 69 & 22 & 35 & 33 & 50 & 44 & 42 & 34 & 26 \\
\hline & GP & 41 & 55 & 59 & 87 & 62 & 44 & 58 & 60 & 56 & 64 & 62 & 57 & 61 & 59 & 53 & 68 & 56 & 58 & 56 & 51 & 48 \\
\hline$\# 2$ & PJ & 55 & 79 & 73 & 81 & 76 & 52 & 73 & 76 & 86 & 83 & 68 & 74 & 83 & 76 & 61 & 83 & 84 & 69 & 71 & 75 & 68 \\
\hline & GJ & 56 & 49 & 77 & 80 & 77 & 61 & \begin{tabular}{|l|}
72 \\
\end{tabular} & 78 & 100 & 100 & 56 & 81 & 62 & 84 & 63 & 88 & \begin{tabular}{|l|}
91 \\
\end{tabular} & 75 & 64 & 71 & 54 \\
\hline & GP & 60 & 74 & 72 & 93 & 74 & 69 & 71 & 75 & 91 & 90 & 79 & 68 & 76 & 72 & 59 & 85 & 73 & 66 & 77 & 78 & 58 \\
\hline$\# 3$ & PJ & 72 & 82 & 86 & 86 & 85 & 66 & \begin{tabular}{|l|}
84 \\
\end{tabular} & 81 & 100 & 91 & 78 & 86 & 84 & 83 & 74 & 61 & 90 & 83 & 76 . & 86 & 84 \\
\hline & GJ & 76 & 74 & 73 & 70 & 81 & 35 & 74 & 67 & 63 & 0 & 54 & 82 & 100 & 80 & \begin{tabular}{|l|}
61 \\
\end{tabular} & 75 & 85 & 53 & 79 & 64 & 72 \\
\hline & GP & 66 & 87 & 96 & 95 & 84 & 94 & 86 & 86 & 87 & 88 & 96 & 82 & 68 & 92 & 85 & 90 & 82 & 83 & 87 & 81 & 87 \\
\hline$\# 4$ & PJ & 70 & 89 & 95 & 95 & 90 & 94 & 91 & 87 & 100 & 94 & 95 & 92 & 88 & 81 & 87 & 85 & 96 & 87 & 86 & 92 & 93 \\
\hline & GJ & 71 & 82 & 80 & 92 & 87 & \begin{tabular}{|l|}
83 \\
\end{tabular} & 84 & 89 & 74 & 100 & 76 & 89 & 100 & \begin{tabular}{|l|}
91 \\
\end{tabular} & \begin{tabular}{|l}
78 \\
\end{tabular} & 100 & 91 & 80 & 83 & 80 & 86 \\
\hline & GP & 42 & 43 & 57 & 83 & 54 & 56 & 50 & 59 & 83 & 68 & 66 & 52 & 56 & 72 & 26 & 78 & 59 & 50 & 52 & 45 & 35 \\
\hline$\# 5$ & PJ & $3 \overline{33}$ & \begin{tabular}{|l|}
44 \\
\end{tabular} & 61 & 67 & 58 & 38 & 54 & 62 & 73 & 68 & 54 & 60 & 51 & 39 & \begin{tabular}{|l|}
48 \\
\end{tabular} & 74 & 74 & 54 & 50 & 56 & 34 \\
\hline & GJ & 35 & \begin{tabular}{|l|}
25 \\
\end{tabular} & 53 & 66 & 59 & \begin{tabular}{|l|}
44 \\
\end{tabular} & 54 & 56 & 100 & 0 & 72 & \begin{tabular}{|l|}
63 \\
\end{tabular} & 58 & \begin{tabular}{|l|}
50 \\
\end{tabular} & \begin{tabular}{|l|}
44 \\
\end{tabular} & 50 & 81 & 61 & 32 & 56 & \begin{tabular}{|l}
38 \\
\end{tabular} \\
\hline & $G P$ & 39 & 59 & 64 & 74 & 58 & 58 & 54 & 62 & 58 & 64 & 75 & 48 & 56 & 82 & 57 & 59 & 72 & 40 & 75 & 66 & 41 \\
\hline$\# 6$ & PJ & 33 & 50 & 52 & 20 & 56 & 54 & 57 & 58 & 78 & 64 & 54 & \begin{tabular}{|l|}
63 \\
\end{tabular} & \begin{tabular}{|c|}
65 \\
\end{tabular} & 39 & 48 & 82 & \begin{tabular}{|l|}
76 \\
\end{tabular} & 58 & 39 & 52 & 49 \\
\hline & GJ & 12 & 13 & 38 & 84 & 55 & 66 & \begin{tabular}{|l|}
54 \\
\end{tabular} & 63 & 74 & 100 & 70 & 69 & \begin{tabular}{|l|}
74 \\
\end{tabular} & 52 & 34 & 86 & 79 & 71 & 34 & 49 & 27 \\
\hline & GP & 28 & 28 & 39 & 42 & 34 & 33 & 28 & 39 & 42 & 26 & 47 & 41 & 7 & 32 & 27 & 38 & 41 & 36 & 33 & 22 & 25 \\
\hline$\# 7$ & PJ & 30 & \begin{tabular}{|l|}
33 \\
\end{tabular} & 33 & 41 & 39 & 13 & \begin{tabular}{|l|}
35 \\
\end{tabular} & \begin{tabular}{|l|}
37 \\
\end{tabular} & 53 & 14 & 37 & 44 & \begin{tabular}{|l|}
30 \\
\end{tabular} & 15 & 48 & 52 & 42 & 29 & 33 & 34 & 34 \\
\hline & GJ & 50 & 48 & 42 & 40 & 47 & 20 & \begin{tabular}{|l|}
43 \\
\end{tabular} & 43 & 26 & 0 & 59 & 53 & \begin{tabular}{|l|}
38 \\
\end{tabular} & 27 & $4 !$ & 43 & 38 & 26 & 54 & 45 & 28 \\
\hline & GP & 29 & 36 & 35 & 59 & 38 & 38 & 36 & 39 & 54 & 47 & 32 & 37 & 38 & 60 & 29 & 47 & 44 & 33 & 36 & 17 & 42 \\
\hline \#8 & PJ & 18 & \begin{tabular}{|l|}
22 \\
\end{tabular} & 46 & 62 & 41 & 44 & \begin{tabular}{|l|}
44 \\
\end{tabular} & 37 & 67 & 61 & 52 & \begin{tabular}{|l|l|}
30 \\
\end{tabular} & 46 & 31 & 29 & 44 & 54 & 56 & 31 & 26 & 43 \\
\hline & GJ & 18 & 4 & 23 & 62 & 35 & 63 & 37 & 43 & 0 & 100 & 57 & 52 & 57 & 23 & 27 & 71 & 79 & 56 & 14 & 29 & 13 \\
\hline & GP & 48 & 62 & 63 & 90 & 63 & 70 & 61 & 65 & 66 & 67 & 73 & 55 & 59 & 69 & 67 & 85 & 62 & 54 & 79 & 47 & 50 \\
\hline$\# 9$ & PJ & 42 & \begin{tabular}{|l|}
63 \\
\end{tabular} & 80 & 80 & 71 & 81 & 71 & 76 & 90 & 92 & 74 & 71 & \begin{tabular}{|c|}
54 \\
\end{tabular} & 64 & 65 & 89 & \begin{tabular}{|l|}
94 \\
\end{tabular} & \begin{tabular}{ll|}
69 \\
\end{tabular} & 71 & 56 & 64 \\
\hline & GJ & 38 & \begin{tabular}{|l|}
37 \\
\end{tabular} & 55 & 86 & 64 & \begin{tabular}{|l|}
87 \\
\end{tabular} & 66 & 73 & 74 & 100 & 63 & 72 & 67 & 73 & 59 & 88 & \begin{tabular}{|c|}
93 \\
\end{tabular} & 90 & \begin{tabular}{|l|}
58 \\
\end{tabular} & 56 & 47 \\
\hline & 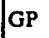 & 53 & 44 & 63 & 83 & 59 & 63 & 48 & 69 & 79 & 69 & 61 & 59 & 63 & 32 & 48 & 74 & 64 & 60 & 58 & 45 & 40 \\
\hline$\# 10$ & PJ & 38 & 54 & 60 & 77 & 60 & 64 & 55 & 73 & 58 & \begin{tabular}{|l|l|}
74 \\
\end{tabular} & 63 & \begin{tabular}{|l|}
64 \\
\end{tabular} & \begin{tabular}{|l|}
59 \\
\end{tabular} & 43 & 53 & \begin{tabular}{|c|}
39 \\
\end{tabular} & 85 & \begin{tabular}{|l|}
73 \\
\end{tabular} & 51 & 52 & 33 \\
\hline & GJ & 41 & 28 & 37 & 66 & 47 & 65 & 51 & 53 & 74 & \begin{tabular}{|l|}
50 \\
\end{tabular} & 40 & 52 & \begin{tabular}{|l|}
57 \\
\end{tabular} & 61 & 42 & 75 & 72 & 45 & 43 & 39 & 34 \\
\hline & $G P$ & 51 & 63 & 67 & 72 & 69 & 22 & 61 & 63 & 76 & 70 & 62 & 58 & 72 & 72 & 50 & 62 & 50 & 63 & 62 & 65 & 67 \\
\hline |\#11 & PJ & 58 & \begin{tabular}{|l|}
59 \\
\end{tabular} & 73 & 90 & 75 & 52 & 71 & 83 & \begin{tabular}{|l|l|}
100 \\
\end{tabular} & 81 & 83 & 76 & 67 & 62 & 60 & 89 & 951 & 71 & 70 & 54 & 75 \\
\hline & GJ & 47 & \begin{tabular}{|l|}
82 \\
\end{tabular} & 72 & 77 & 75 & 70 & 74 & 73 & 63 & \begin{tabular}{|l|}
100 \\
\end{tabular} & 90 & 79 & 64 & 66 & 71 & \begin{tabular}{|l|}
88 \\
\end{tabular} & 90 & 62 & \begin{tabular}{l|l|}
82 & \\
\end{tabular} & 76 & 55 \\
\hline & GP & 48 & 56 & 67 & 58 & 58 & 60 & 55 & 61 & 50 & 56 & 38 & 56 & 57 & 78 & 65 & 49 & 45 & 58 & 55 & 77 & 72 \\
\hline$\# 12$ & PJ & 62 & 66 & 54 & 62 & 61 & 50 & \begin{tabular}{|l|}
57 \\
\end{tabular} & 71 & 77 & 45 & 58 & 74 & 47 & 45 & 64 & 78 & 53 & 52 & 57 & 73 & 54 \\
\hline & GJ & 71 & 72 & 77 & 43 & 60 & 53 & 64 & 51 & 26 & 50 & 47 & 62 & 48 & 57 & 70 & \begin{tabular}{|l|}
57 \\
\end{tabular} & \begin{tabular}{|l|l}
33 \\
\end{tabular} & 44 & \begin{tabular}{l|l|}
75 \\
\end{tabular} & 72 & 59 \\
\hline & GP & 61 & 71 & 75 & 90 & 72 & 78 & 72 & 73 & 86 & 96 & 87 & 63 & 87 & 74 & 56 & 89 & 80 & 66 & 76 & 76 & 49 \\
\hline$\# 13$ & PJ & 58 & \begin{tabular}{|l|}
70 \\
\end{tabular} & 82 & 95 & 80 & 76 & 79 & 78 & 90 & \begin{tabular}{|l|}
98 \\
\end{tabular} & 88 & 90 & 73 & 67 & 55 & 89 & 100 & 90 & 70 & \begin{tabular}{|l|}
53 \\
\end{tabular} & 82 \\
\hline & GJ & 41 & 34 & 78 & 93 & 76 & 90 & 77 & 80 & 100 & \begin{tabular}{|l|}
100 \\
\end{tabular} & 84 & 89 & 88 & 74 & 60 & 100 & 100 & \begin{tabular}{|l|l|}
80 & \\
\end{tabular} & 58 & 75 & 66 \\
\hline
\end{tabular}

* The most conservative response is "agree" on statements $2-6,8-11,13$, and 19-22; "disagree" on statements 1, 7, 12, and 23; "defendant must prove innocence" on 14; "vote guilty" on 15; and "older, experienced people" on 24. 
TABLE 11 (continued)

\begin{tabular}{|c|c|c|c|c|c|c|c|c|c|c|c|c|c|c|c|c|c|c|c|c|c|c|}
\hline \multicolumn{2}{|c|}{\begin{tabular}{|c|} 
Opinion \\
Statements \\
\end{tabular}} & \multicolumn{4}{|c|}{ Age } & \multicolumn{2}{|c|}{ Race } & \multicolumn{2}{|c|}{ Sex } & \multicolumn{7}{|c|}{ Occupation } & \multicolumn{6}{|c|}{ Income } \\
\hline & & $\begin{array}{l}18- \\
30\end{array}$ & $\begin{array}{l}31- \\
45 \\
\end{array}$ & & $\begin{array}{l}61- \\
75\end{array}$ & \multicolumn{2}{|c|}{ 总客总 } & \multicolumn{2}{|c|}{ 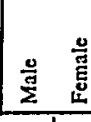 } & \multicolumn{4}{|c|}{ 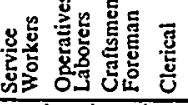 } & \multicolumn{3}{|c|}{ 昜 } & \multicolumn{6}{|c|}{ 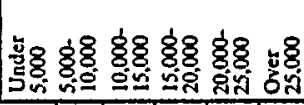 } \\
\hline \multirow{3}{*}{$\# 14$} & GP & 40 & 36 & 45 & 61 & 40 & 69 & 34 & 56 & 76 & 51 & 45 & 36 & 66 & 36 & 22 & 62 & 61 & 41 & 34 & 43 & 23 \\
\hline & PJ & 36 & 16 & 28 & 40 & 30 & 21 & 28 & 38 & 20 & 36 & 32 & 39 & 24 & 21 & 20 & 22 & 64 & 34 & 26 & 13 & 14 \\
\hline & GJ & 12 & 4 & 23 & 30 & 22 & 33 & 22 & 30 & 74 & 0 & 21 & 34 & 34 & 6 & 16 & 43 & 41 & 24 & 19 & 17 & 10 \\
\hline \multirow{3}{*}{$\# 15$} & GP & 23 & 21 & 19 & 34 & 24 & 19 & $2 I$ & 26 & 35 & 26 & 38 & 22 & 19 & 16 & 14 & 33 & 23 & 23 & 19 & 31 & 14 \\
\hline & PJ & \begin{tabular}{|l|}
22 \\
\end{tabular} & 14 & 23 & 26 & 23 & 13 & 24 & 12 & 47 & 30 & 26 & 15 & 12 & 24 & 18 & 18 & 32 & 26 & 20 & 10 & 20 \\
\hline & GJ & 12 & 13 & 9 & 47 & 28 & 35 & 25 & 40 & 74 & 100 & 30 & 36 & 36 & 18 & 13 & 86 & 35 & 31 & 5 & 20 & 19 \\
\hline \multirow{3}{*}{$\# 19$} & GP & 44 & 39 & 49 & 62 & 50 & 33 & 36 & 58 & 51 & 43 & 44 & 63 & 59 & 42 & 26 & 65 & 52 & 50 & 40 & 32 & 24 \\
\hline & PJ & 27 & 30 & 39 & 41 & 38 & 14 & 34 & 53 & 40 & 45 & 37 & 37 & 38 & 31 & 28 & 33 & 34 & 39 & 32 & 45 & 28 \\
\hline & GJ & 29 & 8 & 12 & 26 & 22 & 7 & 18 & 20 & 37 & 0 & 15 & 21 & 52 & 18 & 13 & 25 & 44 & 9 & 21 & 16 & 9 \\
\hline \multirow{3}{*}{$=20$} & GP & 12 & 20 & 31 & 41 & 24 & 30 & 20 & 31 & 68 & 25 & 26 & 28 & 30 & 18 & 9 & 47 & 39 & 25 & 7 & 20 & 10 \\
\hline & PJ & 20 & 13 & 28 & 47 & 32 & 5 & 28 & 35 & 20 & 38 & \begin{tabular}{|c|}
38 \\
\end{tabular} & 33 & 15 & $\overline{13}$ & 28 & 22 & 56 & \begin{tabular}{|l|}
34 \\
\end{tabular} & 24 & 20 & 12 \\
\hline & GJ & 6 & 4 & 15 & \begin{tabular}{|l|}
38 \\
\end{tabular} & 21 & 40 & 24 & \begin{tabular}{|l|}
24 \\
\end{tabular} & 0 & 100 & 11 & 42 & 46 & 0 & 15 & 75 & \begin{tabular}{|l|}
35 \\
\end{tabular} & \begin{tabular}{|l|}
14 \\
\end{tabular} & 7 & 36 & 5 \\
\hline \multirow{3}{*}{$\neq 21$} & GP & 7 & 7 & 8 & 33 & 12 & 12 & 9 & 16 & 24 & 10 & 29 & 5 & 12 & 20 & 7 & 24 & 26 & 9 & 9 & 6 & 0 \\
\hline & PJ & 2 & 9 & 13 & 18 & 13 & 8 & 12 & 16 & 10 & $\begin{array}{l}36 \\
\end{array}$ & 12 & 9 & 9 & 5 & 2 & 26 & 14 & 29 & 2 & 5 & 4 \\
\hline & GJ & 0 & 0 & 3 & 25 & 12 & 21 & 11 & 20 & 0 & 50 & 0 & 24 & 34 & 0 & 8 & 38 & 29 & \begin{tabular}{|l|}
17 \\
\end{tabular} & 10 & 0 & 0 \\
\hline \multirow{3}{*}{$\# 22$} & GP & 13 & 18 & 28 & 66 & 30 & 17 & 24 & 34 & 61 & 31 & 30 & 30 & 29 & 32 & 14 & 60 & 33 & 28 & 15 & 13 & 19 \\
\hline & PJ & 10 & 9 & 20 & 37 & 23 & 8 & 20 & 23 & 10 & 42 & 32 & 24 & 11 & 11 & 10 & 15 & 35 & 30 & 19 & II & 8 \\
\hline & GJ & 6 & 0 & 9 & 28 & 15 & 28 & 16 & .17 & 0 & 50 & 51 & 20 & 17 & 12 & 6 & 50 & 44 & \begin{tabular}{|l|}
17 \\
\end{tabular} & 10 & 7 & 2 \\
\hline \multirow{3}{*}{$\# 23$} & GP & 13 & 30 & 36 & 29 & 26 & 30 & 28 & 28 & 33 & 28 & 40 & 24 & 28 & 14 & 24 & 13 & 16 & 36 & 38 & 29 & 33 \\
\hline & PJ & \begin{tabular}{|l|}
24 \\
\end{tabular} & 42 & 21 & 37 & 10 & 29 & 29 & 28 & 33 & 36 & 39 & 33 & 25 & 22 & 22 & 52 & 47 & \begin{tabular}{|l|}
35 \\
\end{tabular} & 29 & \begin{tabular}{|l|}
21 \\
\end{tabular} & 12 \\
\hline & $\mathrm{GJ}$ & 36 & 24 & 42 & 41 & 41 & \begin{tabular}{|l|}
24 \\
\end{tabular} & 41 & 36 & 26 & 0 & 23 & 35 & 38 & 52 & 43 & 57 & 12 & \begin{tabular}{|l|}
18 \\
\end{tabular} & 44 & 33 & 38 \\
\hline \multirow{3}{*}{$\# 24$} & GP & 10 & 18 & 25 & 50 & 23 & 28 & 24 & 25 & 50 & 36 & 32 & 11 & 24 & 18 & 15 & 38 & 28 & 19 & 24 & 30 & 9 \\
\hline & PJ & 10 & 14 & 32 & 47 & 30 & 25 & 28 & 44 & 22 & 36 & 46 & 31 & 24 & 20 & 18 & 30 & 46 & 36 & 24 & 22 & 18 \\
\hline & GJ & 6 & 8 & 15 & 45 & 25 & 40 & 32 & 23 & \begin{tabular}{|l|}
37 \\
\end{tabular} & 50 & 0 & 44 & 29 & 20 & 22 & 38 & 44 & 45 & 5 & 16 & 20 \\
\hline
\end{tabular}


APPENDIX D: TABLE 12

The demographic characteristics of the Queens County population are compared with the characteristics of the United States population in the table.

TABLE 12

Comparison of Demographic Characteristics of QueEns County and General U.S. Population

U.S.

\section{Age}

Under 18 Years

18-64

65 and over

Median Age

$\underline{\text { Race }}$

White

Nonwhite

Nationality-Heritage

Foreign-born

Native-born of foreign or mixed parentage

Education

Persons 25 and over:

median school years attended

Children in private elementary schools

12.1 Years

12.0 Years

$11.5 \%$

$35.8 \%$

Economics

Median income

Below poverty level

Incomes of $\$ 15,000$ or more

In white-collar positions

Queens

$\begin{array}{ll}34.3 \% & 26.2 \% \\ 55.9 \% & 61.4 \% \\ 9.9 \% & 12.4 \% \\ \text { 28.1 Years } & 35.5 \text { Years }\end{array}$

$\begin{array}{ll}87.5 \% & 85.3 \% \\ 12.5 \% & 14.7 \%\end{array}$

$4.7 \% \quad 21.0 \%$

$11.8 \% \quad 29.5 \%$

These data from the 1970 United States Census show that the Queens County population is distinctly older than the country's population. The median age of Queens County residents was 35.5 years, 7.4 years older than the median age of the country's population.

The racial make-up of Queens County differs little from that of the national population. Nonwhites made up $14.7 \%$ of the Queens County population and $12.5 \%$ of the population of the United States. More significantly, however, $50.5 \%$ of Queens County was either foreign-born or of foreign or mixed parentage. This compares to $16.5 \%$ in the general population.

Of those Queens County residents 25 and over, the median num- 
ber of years of schools attended, 12.0, is nearly identical to that for the nation. But, substantially more children from Queens County are privately educated $35.8 \%$ of the elementary school children in Queens County but only $11.5 \%$ in the general population were in private schools in 1970).

The percentage of Queens County residents in white-collar jobs in $1970,60.3 \%$, was twelve points higher than the corresponding percentage of the nation's work force. The median income in 1970, $\$ 11,555$, was almost two-thousand dollars over the national median. Five and a half percent of Queens County residents were living below the poverty level compared with $10.7 \%$ in the United States. The percentage of those earning $\$ 15,000$ or more was $30.8 \%$ in Queens County, $20.6 \%$ nationally. 